\title{
BERKSHIRE'S BLEMISHES: LESSONS FOR BUFFETT'S SUCCESSORS, PEERS, AND POLICY
}

\author{
Lawrence A. Cunningham*
}

Berkshire Hathaway's unique managerial model is lauded for its great value; this Article highlights its costs. Most costs stem from the same features that yield such great value, which boil down, ironically, to Berkshire trying to be something it isn't: it is a massive industrial conglomerate run as an old-fashioned investment partnership. An advisory board gives unchecked power to a single manager (Warren Buffett); Buffett makes huge capital allocations and pivotal executive hiring-and-firing decisions with modest investigation and scant oversight; Berkshire's autonomous and decentralized structure grants operating managers enormous discretion with limited second-guessing; its trustbased culture relies on a cultivated vision of integrity more than internal controls; and its thrifty anti-bureaucracy means no central departments, such as public relations or general counsel.

Delineating the visible costs of Berkshire's model confirms the desirability of tolerating many of them, given the value concurrently generated, but also reveals ways to improve the model-a few while Buffett is at the helm, but mostly for successors. Current reform suggestions include hiring a fulltime public relations professional at headquarters and more systematically developing senior executives; suggestions for future reform include enhanced subsidiary compliance

* (c) 2016. All Rights Reserved by Lawrence A. Cunningham, Henry St. George Tucker III Research Professor, George Washington University. Thanks for comments to Stephanie Cuba, Anupreeta Das, Chris Goulakos, Brian Tayan, and Jason Zweig; for research assistance to Gia Arney; and to the audience at the Museum of American Finance where I delivered this paper as the keynote address for its symposium on the Fiftieth Anniversary of Warren Buffett's Berkshire Hathaway. 
resources and separating the identity and personal opinions of top executives from the corporation and its official policy.

Besides helping Berkshire, the review and suggestions will help managers of other companies inspired by Buffett's unique managerial model and policymakers who should study it. Implications for peers and policymakers include highlighting flexibility in corporate governance, the efficacy of the conglomerate form, and especially the value of strategies that produce long-term thinking among shareholders and managers alike.

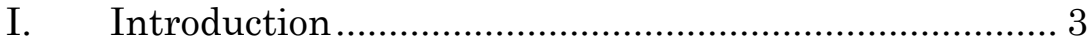

II. Issues and Lessons for Berkshire.............................. 7

Table 1: Costs of Berkshire's Blemishes vs. Modest Prescriptions ....................................................... 8

A. Error Risks of Self-Reliance in Capital Allocation ............................................................ 9

B. Crisis Costs in Severing Autonomous Executives ............................................................ 14

C. Externalities of Decentralization: Consumers/Workers .......................................... 18

D. Reputation Risks of Skimping on Public Relations

E. Hypocrisy Charges and Uncertainty Due to Alter Ego ........................................................ 34

F. Miscellaneous: Public Family Firms and The Tenure Myth ................................................... 39

G. Coda: Partnership Manqué ................................. 42

III. Implications for Peers and Policy .............................. 43 Table 2: Value of Berkshire's Practices vs.

Corporate America................................................ 43

A. Governance and Culture ................................... 45

1. Board Role.................................................. 45

2. CEO Power.................................................... 46

3. Control Versus Trust..................................... 47

B. The Conglomerate Form .................................... 49

C. Activism, Hostility, and Defense ....................... 54

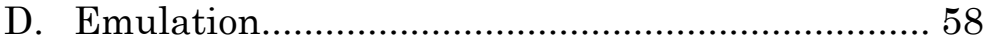

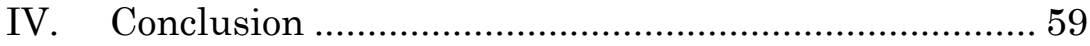


"We would rather suffer the visible costs of a few bad decisions than incur the many invisible costs that come from decisions made too slowly_or not at all_because of a stifling bureaucracy."

—Warren Buffett, 2009 Letter to Shareholders

\section{INTRODUCTION}

This Article examines the visible costs of Berkshire Hathaway's ("Berkshire" or "BRK") unique managerial model, highlighting the lessons for Berkshire and the implications for peers and policymakers. Most such costs derive from the same features that have produced substantial value at Berkshire, which ironically are due to Berkshire trying to be something it is not: Warren Buffett's giant industrial conglomerate is organized and operated as if it were still the old-fashioned investment partnership of its early years. Costs arise from the empowerment of a single individual to make multi-billion dollar decisions with scant oversight, devolution of operating decisions to disparate individuals running its scores of diverse subsidiaries, and a culture based on a cultivated sense of integrity rather than conventional internal controls. While the net benefits are vast, tallying the costs illuminates how the model might be improved, especially after Buffett leaves the scene in the next decade or so.

The most visible-and measurable-costs of the Berkshire model appear in capital allocation, principally acquisitions and investments. Buffett relies on himself in making these decisions, without board or executive input or oversight. While most such decisions have succeeded, many spectacularly so, some bloopers have appeared, the bestknown being Dexter Shoe and Gen Re. The costs of error from such self-reliance could readily be mitigated by broader distribution of decision-making power. Buffett does so by periodically consulting vice chairman Charles Munger. Yet since the net costs of this approach have been modest, thanks to Buffett's acumen and stature, there is no reason 
for reform while Buffett is at the helm. But some additional power-sharing and oversight would be appropriate for his successors, as Berkshire's succession plan contemplates.

The more dramatic costs of the Berkshire model arise from executive departures and succession at the subsidiaries. While most Berkshire managers have excelled and the company generally retains managers for lengthy tenures, there are exceptions that become costly because they suggest crisis. The stakes have been particularly high on the occasions involving executives considered likely successors to Buffett, such as David Sokol and Richard Santulli. The drama of Berkshire executive shuffles arises in part from Buffett being the company's sole decision maker, but it is magnified by Berkshire's lack of formal vetting, training, grooming, and talent review protocols. This problem should be remedied now, while Buffett is at the helm, and there is evidence of increased coordination and discussion among Berkshire subsidiary chief executive officers ("CEOs"), which should intensify as Berkshire moves beyond Buffett.

Berkshire's decentralized structure produces a third category of costs, those inflicted on customers or employees. At a sprawling business organization with hundreds of units and hundreds of thousands of employees, such externalities are inevitable. Known historical examples at specific Berkshire subsidiaries include questionable practices of certain distributors of Kirby vacuums and inhumane conditions at Fruit of the Loom's overseas manufacturing facilities. More generally, consumer advocates critique some products that Berkshire companies and investees marketsuch as See's candies, Coca-Cola's carbonated beverages, and Kraft's processed foods. ${ }^{1}$ Labor advocates challenge treatment of the workforce by co-investors, especially by $3 \mathrm{G}$,

1 See, e.g., Zachary Tracer, Kraft a Menu at the Buffett Buffet With Warren's Latest Deal, BLOOMBERG Bus. (Mar. 25, 2015), http:// www.bloomberg.com/news/articles/2015-03-25/kraft-a-menu-at-the-buffettbuffet-with-warren-s-latest-deal [http://perma.cc/LQU3-DJPA]; Kyle Stock, Warren Buffett is Bad for Your Health, BloomBerg Bus. (Mar. 25, 2015), http://www.bloomberg.com/news/articles/2015-03-25/warren-buffett-is-badfor-your-health [http://perma.cc/5658-HSQN]. 
the Brazilian private equity firm with which Berkshire has co-invested in H.J. Heinz and Kraft. While such costs are tolerable with Buffett at the helm, and the benefits of decentralization should be sustained once he's gone, Berkshire will need to invest more resources in conglomerate-wide internal control and reporting in the coming years.

Subtler costs arise from Berkshire's zealous thriftiness that leave it without a centralized communications or public relations department. Given Berkshire's scale and reach, however, along with relatively opaque disclosure about many operations, it attracts investigative journalists targeting subsidiaries for critical exposure and sometimes political or legal advantage. Subsidiaries as diverse as National Indemnity and Clayton Homes appeared flatfooted as targets of corporate exposés, in part because of Berkshire's lack of a centralized communications or public relations department. ${ }^{2}$ Respecting as laudable the thrifty anti-bureaucratic impulse, the company would nevertheless do well now to hire a professional to handle Berkshire's overall public relations, for both parent-level communications and to coordinate that of subsidiaries.

The most significant historical cost of the Berkshire model has been widespread treatment of Berkshire as Buffett's alter ego, a natural propensity given his long-time controlling ownership and dominating leadership. It became a cost, however, as Buffett became outspoken in offering his personal views on a range of hot topics on which Berkshire may act differently-or critics so perceive, and charge hypocrisy. Examples: Buffett urges more progressive taxation while Berkshire pursues tax-advantaged transactions ${ }^{3}$ Buffett criticizes financial intermediaries

2 See Lawrence A. Cunningham, Warren Buffett and Wall Street: The Best of Frenemies, Fin. Hist., Fall 2015, at 16, http://www.moaf.org/ publications-collections/financial-history-magazine/115/_res/id=sa_File1/

Warren\%20Buffett\%20and\%20Wall\%20Street.pdf [http://perma.cc/497DDV5Q]; infra text accompanying notes 60-99.

3 See, e.g., Jim Puzzanghera, Burger King, Warren Buffett Under Fire for Canadian Inversion Deal, L.A. TIMES (Aug. 26, 2014), http://www. 
while Berkshire's portfolio holds substantial stakes in them; ${ }^{4}$ and Buffett publicly stated his support for the Keystone oil pipeline despite how it would compete with Berkshire's BNSF Railway. ${ }^{5}$

Although these costs cannot be tackled with Buffett at Berkshire's helm, successors can avoid them by reticenceexecutive behavior that clearly distinguishes the company from its personnel, including refraining from offering personal opinions in public debates. Another cost of this alter ego phenomenon, which has received the greatest publicity, is the most intractable: concern about the fate of the company, after the man passes.

To summarize, the principal sources of the costs of Berkshire's model are self-reliance, a culture of autonomy and trust, decentralization, thrift, and alter ego. Resulting costs may be categorized as the costs of error, crisis, externalities, reputation, and uncertainty. Corrective measures to enact now are incrementally greater leadership coordination, increased grooming to minimize the costs of succession crises, and hiring of a professional public relations expert to protect reputation. Measures to enact in due course are slightly wider sharing of decision-making power over capital allocation to neutralize error risk; modest strengthening of internal reporting controls to police against externalities; and maintenance of executive reticence on matters of public policy to avoid the costs of treating Berkshire's leadership as synonymous with the company.

latimes.com/business/la-fi-burger-king-tim-hortons-boyctott-warrenbuffett-20140826-story.html [http://perma.cc/PG8B-Y8NP]; infra text accompanying notes 100-15.

4 See Dale A. Oesterle, Revisiting the Anti-Takeover Fervor of the '80s Through the Letters of Warren Buffett, 19 CARDOzo L. REV. 565, 573-77 (1997); see also infra note 104 and accompanying text.

5 See Stephen Gandel, Warren Buffett: "I Would Have Passed Keystone," ForTunE (Mar. 2, 2015), http://fortune.com/2015/03/02/warrenbuffett-i-would-have-passed-keystone/ [https://perma.cc/WM9Y-5ZED]; Jeremy Bowman, Did Obama Just Do Warren Buffett and Railroad Stocks a Huge Favor? Motley FoOL (Mar. 8, 2015), http://www.fool.com/ investing/general/2015/03/08/obama-did-warren-buffett-railroad-stockshuge-favo.aspx [http://perma.cc/F6W9-47VH]. 
The Berkshire model offers lessons for other companies and policymakers. Given the model's substantial net success, a fundamental prescription is to allow corporations broad leeway in governance design and organizational structure. In their modesty, Berkshire's specific blemishes reaffirm the value of such latitude while attesting to the general appeal of the type-but not the degree-of prevailing governance regulation or practice. Leading examples are having some deliberative body such as a board, but accepting the traditional advisory model rather than insisting on the contemporary monitoring model; allowing even iconic chief executives significant, if restrained, autonomy; leaving substantial room for trust as the basis of an organization, complemented by controls tailored to internal needs rather than imposed by general regulation; and permitting the conglomerate form of organization to flourish under conditions such as those Berkshire has nurtured while assuring the capacity for such institutions to defend themselves against hostile onslaught by corporate raiders or shareholder activists.

\section{ISSUES AND LESSONS FOR BERKSHIRE}

As the ensuing chart tabulates, the following discussion catalogues the costs of Berkshire's model as arising from five traits-self-reliance, autonomy, decentralization, thrift, and alter ego. Each trait's costs are presented in the context where they manifest most saliently and are accompanied by specific illustrations. A prescription concludes each section, principally discussing whether to adjust the trait now or after Buffett leaves the scene. In a couple of miscellaneous settings, tolerance is the best prescription. 
Table 1: Costs of Berkshire's Blemishes vs. Modest Prescriptions

\begin{tabular}{|c|c|c|c|c|}
\hline TRAIT & COST & CONTEXT & EXAMPLES & $\begin{array}{c}\text { PRESCRI- } \\
\text { PTION }\end{array}$ \\
\hline $\begin{array}{l}\text { A. Self- } \\
\text { reliance: BRK } \\
\text { CEO exercises } \\
\text { unbridled } \\
\text { discretion }\end{array}$ & Error risk & $\begin{array}{l}\text { Capital } \\
\text { allocation } \\
\text { (acquisitions } \\
\text { and invest- } \\
\text { ments) }\end{array}$ & $\begin{array}{l}\text { XTRA } \\
\text { Dexter Shoe } \\
\text { Gen Re } \\
\text { TXU }\end{array}$ & $\begin{array}{l}\text { Adjust } \\
\text { post- } \\
\text { Buffett }\end{array}$ \\
\hline $\begin{array}{l}\text { B. Autonomy: } \\
\text { subsidiary } \\
\text { CEOs in trust- } \\
\text { based culture } \\
\text { with hyper- } \\
\text { delegation and } \\
\text { one-man } \\
\text { oversight }\end{array}$ & Crisis & $\begin{array}{l}\text { Executive } \\
\text { departures }\end{array}$ & $\begin{array}{l}\text { NetJets } \\
\text { D. Sokol } \\
\text { Ben. Moore } \\
\text { Gen Re }\end{array}$ & Adjust now \\
\hline $\begin{array}{l}\text { C. Decentrali- } \\
\text { zation: units } \\
\text { operate } \\
\text { independently } \\
\text { without } \\
\text { central control } \\
\text { or reporting }\end{array}$ & $\begin{array}{l}\text { Externali- } \\
\text { ties }\end{array}$ & $\begin{array}{l}\text { Impositions } \\
\text { on } \\
\text { customers/ } \\
\text { workers }\end{array}$ & $\begin{array}{l}\text { Kirby } \\
\text { Company } \\
\text { Fruit of the } \\
\text { Loom } \\
3 \mathrm{G} \\
\text { Heinz/Kraft } \\
\text { Acme Brick }\end{array}$ & $\begin{array}{l}\text { Adjust } \\
\text { post- } \\
\text { Buffett }\end{array}$ \\
\hline $\begin{array}{l}\text { D. Thrift: } \\
\text { zealous anti- } \\
\text { bureaucracy } \\
\text { means no } \\
\text { central } \\
\text { departments, } \\
\text { incl. public } \\
\text { relations }\end{array}$ & $\begin{array}{l}\text { Reputation } \\
\text { risk }\end{array}$ & $\begin{array}{l}\text { Investiga- } \\
\text { tive journal- } \\
\text { ists attack } \\
\text { flatfooted } \\
\text { Goliath }\end{array}$ & $\begin{array}{l}\text { NICO } \\
\text { Clayton } \\
\text { Homes } \\
\text { NV Energy }\end{array}$ & Adjust now \\
\hline $\begin{array}{l}\text { E. Alter Ego: } \\
\text { widespread } \\
\text { view of Buffett } \\
\text { and Berkshire } \\
\text { as } \\
\text { synonymous }\end{array}$ & $\begin{array}{l}\text { Perceived } \\
\text { hypocrisy } \\
\text { Uncertainty }\end{array}$ & $\begin{array}{l}\text { Public } \\
\text { debates } \\
\text { Succession } \\
\text { planning }\end{array}$ & $\begin{array}{l}\text { Tax policy } \\
\text { Financial } \\
\text { Intermedia- } \\
\text { ries }\end{array}$ & $\begin{array}{l}\text { Adjust } \\
\text { post- } \\
\text { Buffett }\end{array}$ \\
\hline
\end{tabular}




\begin{tabular}{|l|l|l|l|l|}
\hline \multicolumn{1}{|c|}{ TRAIT } & \multicolumn{1}{|c|}{ COST } & CONTEXT & EXAMPLES & $\begin{array}{c}\text { PRESCRI- } \\
\text { PTION }\end{array}$ \\
\hline $\begin{array}{l}\text { F. } \\
\text { Miscellaneous }\end{array}$ & $\begin{array}{l}\text { Opportunity } \\
\text { costs }\end{array}$ & $\begin{array}{l}\text { Listed } \\
\text { family } \\
\text { businesses }\end{array}$ & $\begin{array}{l}\text { Clayton } \\
\text { Homes }\end{array}$ & Tolerate \\
& $\begin{array}{l}\text { False } \\
\text { expectations }\end{array}$ & $\begin{array}{l}\text { Actual } \\
\text { Executive } \\
\text { tenure myth }\end{array}$ & departures & \\
\hline
\end{tabular}

\section{A. Error Risks of Self-Reliance in Capital Allocation}

Buffett calls all parent-level shots at Berkshire, on his own, with limited investigation and no oversight, especially concerning acquisitions and investments. Unlike most sizable public companies, Berkshire relies on neither its board of directors nor senior executives to approve acquisitions, nor does it utilize outside advisors to vet deals. Buffett explains his general philosophy to the board but rarely seeks its advance approval; he occasionally consults with vice chairman Charles Munger ahead of time, but not always, and he does not always heed Munger's counsel. ${ }^{6}$ Berkshire rarely uses business brokers or investment bankers to find acquisition targets, but rather relies on an informal network of friends and business associates. ${ }^{7}$ Most suggestions work out well, but not all, entailing some costs of error.

One of Berkshire's most unusual acquisitions occurred in 2001, when Buffett's friend, Julian Robertson, founder of the preeminent Tiger Fund, signaled to Buffett his willingness to sell a large stake in XTRA, the truck leasing company. ${ }^{8}$

6 See Lawrence A. Cunningham, Berkshire Beyond Buffett: The ENDURING VAlue OF VAlues 213 (2014) [hereinafter Cunningham, BERKSHIRE BEYOND BUfFETT]; Lawrence A. Cunningham, Berkshire's Disintermediation: Buffett's New Managerial Model, 50 WAKE ForEST L. REV. 509, 516 (2015).

7 See Cunningham, Berkshire Beyond BuffeTt, supra note 6, at 213.

8 Letter from Warren E. Buffett, Chairman, Berkshire Hathaway, Inc., to Shareholders of Berkshire Hathaway, Inc. (Feb. 28, 2002), 
Buffett upped the ante, proposing to XTRA's board the making of a tender offer to its shareholders, which it endorsed, and Berkshire soon closed the deal. Contrary to Berkshire's usual practice of maintaining both management and operations after an acquisition, within three years, XTRA replaced its CEO, relocated its headquarters, and divested a large part of its asset base. ${ }^{9}$ While such drastic steps are commonly part of the plan of many corporate acquisitions, they are avoided under the Berkshire model. So when such steps are taken at Berkshire-in this case to reduce overhead, improve asset utilization, and boost profits-they are anomalies that can prove costly. Their origin is in the informality of Berkshire acquisitions, especially spontaneously acting on tips by friends and associates and conducting scant due diligence.

While XTRA turned out to be a profitable acquisition, another unusual deal posed disastrous financial results: Berkshire's 1993 acquisition of Dexter Shoe. Berkshire paid $\$ 443$ million-all in Berkshire stock-for the dying New England shoemaker. ${ }^{10}$ The company had been a dynamo, producing millions of shoes in local factories annually. Dexter maintained production in the United States, paying higher wages than rivals and outdid imports from low-wage countries in terms of quality and style.

Despite positive traits, Dexter had a big latent negative: manufacturing costs in the United States were ten times those in China. ${ }^{11}$ Eventually, rivals produced shoes as good as Dexter's but at one-tenth the cost. By 2007, Buffett confessed that acquiring Dexter was the worst deal he ever made, and Berkshire shuttered it. ${ }^{12}$ The cost was the value of

http://www.berkshirehathaway.com/letters/2001pdf.pdf [http://perma.cc/ T9GZ-9VMZ].

9 See Cunningham, Berkshire Beyond Buffett, supra note 6, at 212.

10 Jonathan Stempel, Buffett Calls Dexter Shoe His Worst Deal Ever, REUTERS (Feb. 29, 2008), http://www.reuters.com/article/2008/03/01/usberkshire-buffett-failure-idUSN2921504820080301 [http://perma.cc/A99H$4 \mathrm{NHE}]$.

11 See Cunningham, Berkshire Beyond Buffett, supra note 6, at 29.

12 Stempel, supra note 10. 
the Berkshire stock surrendered, by 2015 nearing an eyepopping $\$ 6$ billion, teaching the perils of using a high quality stock like Berkshire to acquire businesses. ${ }^{13}$

Buffett alone made the mistake-without input from the Berkshire board or his inner circle. One lesson: even the greatest investors and decision makers make costly mistakes. Buffett is aware of this, of course, which is why he often vets proposals with Munger. But while Buffett values Munger's counsel to veto a deal-earning Munger the nickname the "Abominable No Man"-Buffett has not always listened, as the even more costly acquisition of Gen Re attests.

In 1999, Berkshire paid $\$ 22$ billion for Gen Re-all in Berkshire stock (the lesson from Dexter to avoid paying in stock did not appear until 2007). ${ }^{14}$ Buffett and Munger knew that Gen Re, a large reinsurer, maintained a significant derivatives business that posed considerable risk. While Munger suggested avoiding the deal, Buffett figured he would direct managers to close that business unit promptly after closing the deal. But once Berkshire acquired Gen Re, the managers did not do so and, consistent with Buffett's hands-off approach, he did not push them (such reluctance underscores how unusual the post-acquisition shuffles at XTRA were). ${ }^{15}$

Besides patent problems of the derivatives business, more latent challenges also beset Gen Re's wider operations. Buffett had known Ronald Ferguson, Gen Re's chief executive, for many years, and apparently relied heavily on Ferguson's personal knowledge and experience. What neither Buffett nor Ferguson knew, however, was that Gen

13 The real cost was greater than the $\$ 443$ million purchase price since it was paid in Berkshire stock. The stock paid represented 1.6 percent of Berkshire, which in 2007 would have been worth $\$ 3.5$ billion.

14 Press Release, Berkshire Hathaway Inc., Berkshire Hathaway Inc. and General Re Corporation to Merge (June 19, 1998), http://www. berkshirehathaway.com/news/jun1998.html_[http://perma.cc/C7V7-8GJW].

15 Warren E. Buffett \& Lawrence A. Cunningham, The Essays of WARREN BuFFETT: LESSONS FOR CORPORATE AMERICA 151, 155-57 (4th ed. 2016) [hereinafter THE EsSAYs OF WARREN BuFFETT]. 
Re's underwriting discipline and reserving had slipped. ${ }^{16}$ It had under-reserved for risks it covered, which underwriters translated into low prices on subsequent policies. The firm pursued business it should have rejected, including undue concentration in particular risks. From 1999 to 2001, Gen Re incurred underwriting losses totaling $\$ 6.1$ billion; unwinding the derivatives business was both costly and protracted, causing Buffett angst for many years. ${ }^{17}$

Berkshire shareholders voted to approve the Gen $\operatorname{Re}$ transaction, ${ }^{18}$ a vote required because it was structured as a merger, with Berkshire transferring shares to Gen Re holders-unusual features for a Berkshire deal, most of which are acquisitions for cash, which do not require shareholder approval. While shareholder votes can check improvident deals, the Berkshire-Gen Re merger sailed through. True, shareholders of many companies often approve improvident mergers due to ignorance or apathy, but Berkshire shareholders are savvy and seen as partners. Yet, despite such hallmarks, Berkshire's shareholders remain holders of corporate equity, not partners, and are therefore prone to error. Thus, there is a cost of overstating the significance of Berkshire's shareholder body. The

16 Oversight may have been lax too, as a subsequent criminal case against Ferguson and other Gen Re executives questioned the legitimacy of a high-level insurance contract that, prosecutors said, was arranged to facilitate financial fraud by the counterparty, American International Group (“AIG”). See Noah A. Gold, Corporate Criminal Liability: Cooperate, and You Won't Be Indicted, 8 GEO. J.L. \& PUB. PoL'Y 147, 148-52 (2010). The case led to the resignation of both Ferguson and his successor, Joseph Brandon. Id. In a book I wrote with former AIG chairman Hank Greenberg, however, we explained why such allegations were without merit and the related investigations flawed. MAURICE R. GREENBERG \& LAWrence A. Cunningham, The AIG Story 177-79, 185 (2013).

17 Mark A. Hoffman, Warren Buffett Accepts Blame for General Re's Poor Results, Bus. Ins. (Mar. 17, 2002), http://www.businessinsurance .com/article/20020317/ISSUE01/10009254/warren-buffett-accepts-blamefor-general-res-poor-results [http://perma.cc/P2X5-ZC4P]; Steve Jordon, General Re is the Key to Berkshire's Ignition, Underwriting Losses, ОмAHA WORLD-HERALD, Apr. 28, 2002, at 1.

18 Press Release, Berkshire Hathaway, supra note 14. 
shareholders cannot be counted on to veto improvident deals Buffett proposes.

Munger is not only influential, sometimes vetoing deals, but deferential, when Buffett wishes to proceed anyway. In 2007, Buffett invested $\$ 2$ billion in the debt of a leveraged buyout of Texas electric utilities. It soon busted amid the financial crisis, costing Berkshire almost $\$ 900$ million. ${ }^{19}$ Reporting this in 2013, Buffett wrote, "Next time I'll call Charlie." 20 While investment committees, common at most businesses even fractions of Berkshire's size, limit opportunistic capital allocation, instances like this underscore the cost of a one-man investment committee.

Buffett understands the appeal and limits of the model and seems to believe that others besides him can execute it. On the other hand, the Berkshire succession plan envisions splitting the roles of chief executive and chief investment officer and the roles of management from board chairman. Accordingly, the Berkshire succession plan envisions a somewhat tighter leash on Buffett's successor-and, unusually for Berkshire, joins a trendy feature in contemporary governance of splitting the roles of board chairman and chief executive. ${ }^{21}$ That outcome should be continually monitored by Berkshire's board, which should be willing to loosen or tighten it, even if incrementally, as may be indicated by performance from time to time. ${ }^{22}$

19 Letter from Warren E. Buffett, Chairman, Berkshire Hathaway, Inc., to Shareholders of Berkshire Hathaway, Inc. 17 (Feb. 28, 2014) http://www.berkshirehathaway.com/letters/2013ltr.pdf [https://perma.cc/ MZ99-MCZR].

20 Id.

21 See Thuy-Nga T. Vo, To Be or Not to Be Both CEO and Board Chair, 76 BRoOK. L. REV. 65, 73 (2010).

22 For other firms, addressed more fully in Part II below, insisting on a capable decision maker based on core principles and a proven track record seems imperative before opting to follow the Berkshire model. See Lawrence A. Cunningham, The Secret Sauce of Corporate Leadership, WALL ST. J. (Jan. 25, 2015), http://www.wsj.com/articles/lawrence-acunningham-the-secret-sauce-of-corporate-leadership-1422231824 [http:// perma.cc/UET3-K3C7]. At minimum, they should embrace the fundamental Berkshire-Buffett tenet of the circle of competence- 


\section{B. Crisis Costs in Severing Autonomous Executives}

The costs of Berkshire's management structure are most dramatic when senior executives depart after being ensnared in widely-publicized imbroglios. The problems generally arise, in varying degrees, from Berkshire's lack of any formal program of executive recruiting, vetting, talent review, or succession grooming. Buffett pays close attention to manager identity when acquiring a company, but then relies on such managers to appoint successors. At the same time, there is no middle management, so in modern management parlance, a single person has some eighty direct reports. The chief costs are from mistakenly releasing or retaining senior executives in circumstances that suggest crisis. ${ }^{23}$

Crisis was the hallmark of a series of executive shuffles at Berkshire's NetJets subsidiary, which involved two managers on the short list of Buffett successors, Richard Santulli and David Sokol. NetJets, which Santulli founded and led through 2009, is a competitive and capital intensive business with a unionized employee base. ${ }^{24}$ Selling fractional interests in private aircraft to the elite, Santulli conceived of the business as a luxury brand and operated it accordingly. But the company struggled and, amid economic adversity following the 2008 financial crisis, Buffett decided to make a change. Why he did so remains something of a mystery and certainly an anomaly, however, as Buffett rarely secondguesses managers, especially company founders like Santulli.

As NetJets' new CEO, Buffett appointed Sokol, who perceived NetJets to be bloated and forthwith cut costs

allocating capital only to undertakings clearly within the decision maker's capabilities.

23 In addition to the examples of executive succession amid crisis described in this Part, two others occurred in succession at Gen Re amid questions about the legality of a high-level insurance contract with AIG. See supra note 16.

24 See Cunningham, Berkshire Beyond Buffett, supra note 6, at 24, 91-92. 
aggressively. ${ }^{25}$ Unionized employees were furious and a sense of crisis soon engulfed the company. Why Buffett chose Sokol to run NetJets is also a curiosity. Sokol was running Berkshire Hathaway's energy business (then called MidAmerican Energy) and troubleshooting as board chairman at Johns Manville. Buffett has almost never moved a CEO from one Berkshire company to another. ${ }^{26}$ Having the same CEO run two Berkshire companies was unprecedented. But Buffett had grown to trust Sokol immensely, having been introduced to him by one of his most intimate confidants, Walter Scott, a fellow Omaha denizen and Berkshire board member. Buffett's faith, however, was misplaced, as Sokol resigned from all his Berkshire jobs in 2011 after being caught front running - he was accused of insider trading when he bought stock in a public company, Lubrizol, ahead of pitching it to Buffett as a Berkshire acquisition. ${ }^{27}$

At NetJets, Sokol left behind both his cost-cutting business model and a successor, Jordan Hansell. ${ }^{28}$ Sokol had recruited Hansell from Berkshire's energy business, where Hansell had served as general counsel. ${ }^{29}$ NetJets' pilots loved Santulli and lamented his departure; they detested both Sokol and Hansell, and especially their low-cost strategy. ${ }^{30}$

25 Geraldine Fabrikant, Potential Successor to Buffett Has Tough Task, N.Y. Times: DealBooK (Dec. 3, 2009), http://dealbook.nytimes.com/ 2009/12/04/potential-buffett-successor-has-tough-task [http://perma.cc/UE R9-FDN8].

26 See Charles Munger, Munger on 'The Berkshire System,' in THE ESSAYS OF WARREN BUFFETT, supra note 15, at 299, 300.

27 See Edward Greene \& Olivia Schmid, Duty-Free Insider Trading, 2013 Colum. Bus. L. REV. 369, 402 (2013).

28 Noah Buhayar \& Mary Jane Credeur, Sokol Exit Makes Hansell NetJets CEO Two Years From Law Firm, Bloomberg Bus. (Apr. 8, 2011), http://www.bloomberg.com/news/articles/2011-04-08/sokol-exit-makeshansell-netjets-ceo-two-years-after-leaving-iowa-law-firm [http://perma.cc/ 3FNR-N4SE].

29 Id.

30 Marla Matzer Rose, Union Workers Upset with NetJets, Columbus DisPATCH (Dec. 9, 2011), http://www.dispatch.com/content/stories/business/ 2011/12/09/union-workers-upset-with-netjets.html [http://perma.cc/9CCYCBWA]. 
After Santulli left, management-labor relations deteriorated, and during 2013 to 2014 the pilots' union hurled invective at Hansell in aggressive campaigns from the internet to The Wall Street Journal and Omaha World-Herald. ${ }^{31}$ Pilots picketed outside Berkshire's annual meeting in 2014 and 2015. Amid mounting turmoil, in early 2015, Hansell resigned and two Santulli-era executives who left from NetJets earlier that year were recruited back to lead the company. ${ }^{32}$

From these circumstances, it is tempting to infer that Berkshire's acquisition of NetJets was a mistake-and perhaps it belongs in the prior section's list of costly acquisitions that are due to Buffett being Berkshire's sole decision maker. But it also speaks to the lack of any formal programs at Berkshire concerning executive recruiting, review, promotion, or grooming. Sokol had no experience with fractional aviation or much else relevant to leading NetJets, such as consumer or union relations. Sokol selected Hansell, a young lawyer at the energy company, who likewise lacked obviously relevant credentials or experience.

The Sokol episode also revealed other costs about crisis management at Berkshire. After Buffett learned of Sokol's front running, he drafted a press release that drew sharp criticism, as it spoke of "extraordinary" contributions to Berkshire and gave Buffett's opinion that Sokol had done nothing illegal. ${ }^{33}$ Buffett accepted the criticism $^{34}$ and then

31 See NetJets: Lining CEO Pockets at Expense of Pilot Livelihoods, GENUINEQS, http://www.genuineqs.com/qs_ads.html [http://perma.cc/5X BT-DL59].

32 Lawrence Cunningham, Was NetJets Purchase a Mistake for Warren Buffett, BETTY LIU SHOw (June 1, 2015), http://www. bloomberg.com/news/videos/2015-06-01/was-netjets-purchase-a-mistakefor-warren-buffett- [http://perma.cc/X4GX-9G9U].

33 Press Release, Berkshire Hathaway, Warren E. Buffett, CEO of Berkshire Hathaway, Announces the Resignation of David L. Sokol (Mar. 30, 2011), http://www.berkshirehathaway.com/news/mar3011.pdf_[http:// perma.cc/5GZ2-AWQD].

34 Ben Claremon, Notes from the 2011 Berkshire Annual Meeting, THE INOCULATED INVESTOR (May 2, 2011), http://investing.kuchita.com/wp- 
turned the matter over to Berkshire's board audit committee which, with assistance from the law firm Munger, Tolles \& Olson LLP, condemned Sokol for violating Berkshire policies.

The executive shuffles at NetJets resembled successive shuffles at Berkshire's Benjamin Moore paint manufacturing subsidiary. When Berkshire acquired it in 2000, Buffett personally promised to continue its longstanding practice of selling only through independent distributors, despite the rise of powerful big box retailers such as Home Depot and Lowe's. ${ }^{35}$ By 2012, however, after five years at the helm, Denis Abrams was replaced for planning to sell paint through such retailers. ${ }^{36}$ To find a replacement, Buffett turned to his newly-hired management assistant, twentyeight-year-old Tracy Britt Cool. The recently-minted Harvard MBA suggested Robert Merritt, who was installed. But not two years later, Merritt succumbed to the same fate. Surrounding both episodes was an atmosphere of crisis, with distributors and other constituents complaining about the degradation of the company amid wonder about how such a great company could have taken such a deep plunge.

The Benjamin Moore departures reveal two variations on the costs of the Berkshire model as it relates to executive oversight. ${ }^{37}$ The first concerns how executives are chosen at Berkshire, which is through internal and informal means rather than the conventional route of using an external executive search firm. The second cost of the Benjamin Moore shuffles concerns the wisdom of Buffett's commitment to maintain Benjamin Moore's old-fashioned distributorship

content/uploads/2011/04/2011-Berkshire-Annual-Meeting-Notes.pdf [http://perma.cc/7TZZ-8L6S]. 67.

35 See Cunningham, Berkshire Beyond Buffett, supra note 6, at 66-

36 James Covert, Warren Buffett Fired Benjamin Moore CEO after Bermuda Cruise, N.Y. Post (June 15, 2012), http://nypost.com/2012/06/15/ warren-buffett-fired-benjamin-moore-ceo-after-bermuda-cruise [http:// perma.cc/D2BB-T4EY].

37 See Lawrence A. Cunningham, NetJets Shuffle: Costs of Deviations from the Berkshire Model, VALUE WALK (June 1, 2015), http://www. valuewalk.com/2015/06/netjets-ceo-buffett [http://perma.cc/MCK7-4DFW]. 
in the first place. ${ }^{38}$ Two successive CEOs reflected an intuition about the difficulty of exclusively selling paint that way given contemporary distribution channels. Yet they were handcuffed by a commitment made solely by Buffett, which might have been different if vetted through the Berkshire board or a committee, an industry consultant, or at least a group of executives with direct merchandising experience-all of which is alien to the Berkshire model.

The costs of managerial succession crisis could be mitigated by modest expansion of corporate bureaucracy (like asking a board committee's opinion on executive personnel decisions) or slight diminution of the trust-based culture (such as conducting background checks or adding periodic reviews and evaluations). In connection with Berkshire's annual meeting in the past few years, I have observed Berkshire moving in this direction-for example, regular annual meetings of the subsidiary CEOs or sometimes joining the board without Buffett's presence. Buffett's successor will likely organize Berkshire into some dozen divisions whose heads report to headquarters-the model followed at the Marmon Group, a mini-Berkshire created by the fabled Pritzker brothers and now a Berkshire subsidiary. ${ }^{39}$

\section{Externalities of Decentralization: Consumers/Workers}

Buffett delegates nearly unbridled discretion to subsidiary chief executives; many of those likewise delegate power to heads of divisions, and many Berkshire companies

38 See Steve Jordon, Warren Buffett Says He Replaced Benjamin Moore's CEO to Keep a Promise, OMAHA WorLd-Herald (Oct. 16, 2013), http://www.omaha.com/money/warren-buffett-says-he-replaced-benjaminmoore-s-ceo-to/article_1c0cb4b7-b2bc-514e-a6a3-ae9697c2ee6f.html [http:// perma.cc/HMY8-UU6K]; James Covert, Warren Buffett Cans Benjamin Moore CEO, N.Y. Post (Sept. 27, 2013), http://nypost.com/2013/09/27/ warren-buffett-cans-benjamin-moore-ceo [http://perma.cc/89UJ-EJXZ].

39 See Cunningham, Berkshire Beyond Buffett, supra note 6, at $167-73$. 
are premised on decentralization. ${ }^{40}$ The vast majority discharge duties faithfully and without public incident, in accordance with tenets of Berkshire culture, including integrity. But there are exceptions or awkward circumstances that result in mistreatment of consumers and workers.

A chief concern of any decentralized business model is policing personnel, such as when distributors mistreat dealers ${ }^{41}$ or when dealers use illegal high-pressured sales tactics. At Berkshire's Scott Fetzer subsidiary, distributors of Kirby vacuums are autonomous businesses. ${ }^{42}$ But they also represent the brand and company. In the past, some violated company policy on proper marketing and employment practices or even broke consumer protection and fair labor laws. ${ }^{43}$ Private lawsuits and state enforcement actions resulted. ${ }^{44}$ In addition to naming the individual businesses as defendants, these claims often also allege that Scott Fetzer and, therefore by extension, Berkshire are culpable. ${ }^{45}$ Such criticisms appear to have been more common in the 1990s, but they persisted. ${ }^{46}$

Yet avoiding the costs of legal entanglements and liability would require withdrawing distributor autonomy. The company would have to change its entire business model to subject all to comprehensive training, supervision, and remediation. Such an approach imposes direct

$40 I d$.

41 See Lee Howard, Ex-Kirby Employees Can Join Suit, DAY (New London, CT) (Mar. 28, 2012), http://www.theday.com/article/20120328/ BIZ02/303289972 [http://perma.cc/2D2G-4B7T].

42 See Joseph P. Cahill, How Kirby Persuades Consumers to Shell Out $\$ 1,500$ for Vacuum, WALL ST. J. (Oct. 4, 1999), http://www.wsj.com/ articles/SB938991433813279910 [http://perma.cc/V7RR-3M46].

43 See id.; Greg Dawson, Kirby Always Cleaning Up After Others, ORLANDO SENTINEL (Aug. 27, 2004), http://articles.orlandosentinel.com/ 2004-08-27/news/0408261168_1_kirby-distributors-steve-griffith [http://perma.cc/P5G3-3YVM].

44 See Jordan v. Scott Fetzer Co., No. 4:07-CV-80 (CDL), 2009 WL 1885063, at*1 (M.D. Ga. June 30, 2009); Howard, supra note 41.

45 See Jordan, 2009 WL 1885063, at *1.

46 See Dawson, supra note 43. 
administrative costs as well as unobservable costs to entrepreneurship and the spirit of ownership that autonomy showers on self-starters. On balance, the distributorship system's autonomy value has appeared to outweigh such costs.

Berkshire's decentralized structure becomes costlier when combined with its minimalist approach to internal controls. A dramatic example was exposed on the floor of the 2009 Berkshire annual meeting by a former employee of a textile manufacturing operation in Honduras. In the early 2000s, before Berkshire's Fruit of the Loom acquired it, Russell Corporation agreed to produce sportswear adorned with popular logos, including for college and professional basketball teams. ${ }^{47}$ But the goods were made in factories located in China and Honduras that engaged in objectionable conduct. In China, products were manufactured in sweatshops that violated international human rights; in Honduras, company officials boarded up the plant and ousted workers in retaliation for unionization efforts. ${ }^{48}$

Such misbehavior drew the attention of activists across the United States, including a group of college students who demanded that universities terminate the agreements. ${ }^{49} \mathrm{It}$ was not until after the 2009 meeting, however, that Buffett and Fruit's CEO found out about the problem and Fruit corrected the problems. ${ }^{50}$ Information must reach Berkshire headquarters quickly concerning potential subsidiary violations of company policy or law. But the Berkshire model is informal, based heavily on one of the few mandates on subsidiary managers: to report bad news early. Whatever gains arise from such an approach-a trust-based culture based on integrity-some violations occur and escape scrutiny, which are clearly a cost of the Berkshire model. ${ }^{51}$

47 Cunningham, Berkshire Beyond Buffett, supra note 6, at 214.

48 Id.

49 Id.

50 Id. at $214-15$.

51 In October 2014, an employee benefits committee of Berkshire's Acme Brick subsidiary, which includes Acme CFO Judy Hunter, alleged that a 2010 cutback in the company match under Acme's 401(k) plan 
More general criticisms against Berkshire concerning employee relations arose from the partnership deals it has made with $3 \mathrm{G}$, the Brazilian private equity firm famous for downsizing acquisition targets. In 2013, Berkshire and 3G jointly acquired H.J. Heinz Company-which, two years later, merged with Kraft. ${ }^{52}$ In each case, $3 \mathrm{G}$ took charge of operations and proceeded to make major changes, replacing top managers and cutting jobs. ${ }^{53}$ Heinz had conditioned its sale to Berkshire and $3 \mathrm{G}$ on their promise to maintain the company's presence and heritage in Pittsburgh, Heinz's home since its 1869 founding, but no commitment was made about employees or other constituents (a contrast to Buffett's

breached Berkshire's promises, made in its 2000 acquisition agreement, to make no changes in the plan. Complaint at 29-30, Hunter v. Berkshire Hathaway Inc., No. 4:14-cv-00663, 2015 WL 5920283 (N.D. Tex., Aug. 5, 2015). The committee also alleged violations of pension law and said Berkshire used "strong-arm tactics against Acme's management" to freeze accrual of pension benefits. Id. at 1. The benefits committee objected, requesting that Acme's board (which includes Marc Hamburg, Berkshire CFO) restore the match retroactively, along with related earnings. When Berkshire responded by offering to either restore the match but freeze the pension or maintain the match and defer the pension freeze, the committee called this an "ultimatum" and "strong-arm tactic." Id. at 1, 17. The Acme benefits dispute may simply be an internal parent-subsidiary disagreement, pitting Berkshire CFO Hamburg against Acme CFO Hunter. That would be a likely explanation under Berkshire's principle of autonomy, with Buffett letting Hamburg and Hunter duke it out. On the other hand, Buffett takes a special interest in post-retirement benefit plan changes - the subject is one of only six points Buffett requests specific updates on from CEO subsidiaries, an exception to the usual principle of autonomy.

52 Press Release, Berkshire Hathaway, H.J. Heinz Company Enters Into Agreement to Be Acquired by Berkshire Hathaway and 3G Capital (Feb. 14, 2013), http://www.berkshirehathaway.com/news/feb1413.pdf [http://perma.cc/6DWE-BNM6]; Press Release, H.J. Heinz, H.J. Heinz Company and Kraft Foods Group Sign Definitive Merger Agreement to Form The Kraft Heinz Company (Mar. 25, 2015), http://news.heinz.com/ press-release/finance/hj-heinz-company-and-kraft-foods-group-signdefinitive-merger-agreement-form-k [http://perma.cc/73QR-MFQW].

53 See Annie Gasparro, Three More Longtime Executives Leaving Heinz, WALL ST. J. (Jan. 13, 2014), http://www.wsj.com/articles/SB10001 424052702304049704579318663756827846 [http://perma.cc/4YTQ-X3SJ]. 
commitment to distributors when acquiring Benjamin Moore). ${ }^{54}$

Critics of private equity and fans of Berkshire found the partnership incongruous, and raised the criticism at Berkshire's annual meetings. Buffett said "I tip my hat to what the 3G people have done," noting that there were "considerably more people in the job than needed" at the companies 3G bought. ${ }^{55}$ He added: "I hope our Berkshire companies are not being run with more people than they need, either." ${ }^{56}$ Buffett did not directly address the contrast between Berkshire's own style and that of $3 \mathrm{G}$ or private equity generally, leaving many dissatisfied and sustaining rather than quelling perceived hypocrisy. ${ }^{57}$ After all, Berkshire never buys a company knowing of a high headcount ready to be reduced.

54 See Press Release, Berkshire Hathaway, supra note 52; see also supra note 38 and accompanying text.

55 Stephen Foley, Warren Buffett Forced to Defend Relationship with Brazil's 3G Capital, FIN. TIMES (May 3, 2015), http://www.ft.com/intl/ cms/s/0/9a8c39f0-f19f-11e4-88b0-00144feab7de.html\#axzz3s9zwIYi4 [http://perma.cc/RR3B-6NDN].

56 Id.

57 For additional discussion of accusations of hypocrisy as a Berkshire blemish, see infra text accompanying notes 100-12. In the case of coinvesting with $3 \mathrm{G}$, another rationale might have explained the difference between Berkshire's own companies and those in which it co-invests, whether with $3 \mathrm{G}$ or in the open stock market. Berkshire companies define Berkshire culture and related actions are taken entirely in the Berkshire name. The $3 \mathrm{G}$ companies are investments, though large ones, with $3 \mathrm{G}$ in charge and related actions taken in its name. If 3G's downsizing hurt those companies, Berkshire could withdraw from the investment; if they help, Berkshire can continue or even acquire full ownership from 3G.

But besides not being how Buffett explained it, there are costs to such a partnership approach. For one, it relies on a distinction between abstaining from making layoffs directly and financing them for indirect profit. Foley, supra note 55 ("If $3 \mathrm{G}$ destroys rather than improves Heinz/Kraft, then Berkshire can sell, without violating any principle, but if $3 \mathrm{G}$ improves the investee to Berkshire standards, it can acquire the whole. . . . 3G does the work of both getting the deal and making the changes, while Berkshire has an option on the upside, both economic and cultural."). 
Berkshire also faces criticism for participating in the purchase of Kraft, famous as a purveyor of processed and unhealthy foods. Critics likewise question Berkshire investments in other unhealthy consumer products, including candies, carbonated soda, and ice cream. ${ }^{58}$ On the other hand, Buffett and Munger have passed on economically valuable opportunities when bothered by a consumer product, such as tobacco companies. ${ }^{59}$ But if socially responsible investing were a top priority for Berkshire, then a diverse and informed investment committee would be in charge of decisions rather than a single capital allocator.

\section{Reputation Risks of Skimping on Public Relations}

Berkshire is unusual in corporate America for not having a substantial professional communications staff or platoon of lobbyists. ${ }^{60}$ For years, Buffett has boasted about this form of thrift, emphasizing that he writes his own letters and taking pride in presiding over Berkshire's annual shareholders' meeting where he and Munger respond to questions for six hours. ${ }^{61}$ Nor does Berkshire host analyst conference calls or participate in the process of generating earnings guidance. Buffett promises the subsidiaries freedom from such pressure too, whether it is the analysts inquiring about earnings or the press probing corporate affairs.

58 See Tracer, supra note 1; Stock, supra note 1. For that matter, advocates of a host of causes could challenge innumerable Berkshire interests, ranging from environmentalists against coal-fired power plants to human rights advocates boycotting Israeli companies for the country's treatment of Palestinians.

59 This assertion is based on private correspondence in the author's files, which have been verified by editors of the Columbia Business Law Review.

60 An entire academic and professional field is devoted to the topic. See, e.g., Joep Cornelissen, Corporate Communication: A Guide to Theory and Practice (3d ed. 2011); Paul A. Argenti, Corporate COMMUNiCATION (6th ed. 2012).

61 See, e.g., ThE EssAYs OF WARREN BUfFETT, supra note 15, at 34-35 (owner-related business principle number 12), 80 . 
Yet the subsidiaries engage in competitive markets with pressures from rivals, media, and political foes. Berkshire's most important business historically has been insurance, an industry central to the functioning of the American economy, and Berkshire's most substantial investments have been in the financial sector. ${ }^{62}$ Among other Berkshire subsidiaries, Clayton Homes is a significant supplier of low-income housing while Berkshire Hathaway Energy is a force in its industry with an influential voice in the evolution of related national policy. While certain Berkshire subsidiaries maintain public relations specialists or lobbyists, most do not and there is no centralized function for such services. Whether merely a product of image envy in high profile businesses or something more substantive, the costs of corporate exposés can be mitigated by greater coordination and formalization of the public relations function.

One such exposé attacked Berkshire's practice of generating substantial investable funds from insurance float. ${ }^{63}$ Insurance float refers to funds that arise from the fact that policy premiums are paid up front while claims need only be paid, if at all, much later. Buffett frequently describes the appeal of such leverage, explaining that Berkshire is often paid to hold such money-so long as risks are properly priced. ${ }^{64}$ Buffett thus stresses the relative cost of float, noting the importance of disciplined underwriting. But a reporter turned the strategy around on Berkshire, portraying the company's approach as giving insurance personnel perverse incentives to do everything in their power to avoid or delay paying legitimate claims, including acting in bad faith.

62 See infra note 101 and accompanying text.

63 Mark Greenblatt, Berkshire Hathaway Subsidiaries Deny, Delay Asbestos, Hazard Claims, Suits Insiders Allege, ScRIPPS (Oct. 6, 2013), http://www.abcactionnews.com/news/local-news/i-team-investigates/berk shire-hathaway-subsidiaries-deny-delay-asbestos-hazard-claims-suitsinsiders-allege1381113034234 [http://perma.cc/XL8Q-HD75].

64 See, e.g., The EssAYs OF WARREn BuffetT, supra note 15, at 32, $295,299,302$. 
The focus of the October 2013 exposé, by Mark Greenblatt of Scripps, was National Indemnity Company's ("NICO") specialty business in retroactively reinsuring long-tail asbestos and environmental risks, giving a dozen illustrations from the thousands of policies it wrote. ${ }^{65}$ The illustrations involved legal disputes among policyholders, corporate defendants, the original insurer, and Berkshire's companies. The piece spotlighted lawsuits charging bad faith in payment delays or denials, including lawsuits by policyholders against the ceding insurers under the original insurance policies or against NICO alleging wrongful interference with those policies. ${ }^{66}$ The story quoted aspersions from claimants, their lawyers, and insurance industry executives, blaming Berkshire's float philosophy for the problems. ${ }^{67}$

While Greenblatt had reached out to Berkshire and NICO personnel for comment, the recipients did not grant interviews and time constraints made them unable to respond to every written question he posed. ${ }^{68}$ Within days of publication, Berkshire emailed Greenblatt to explain various

65 Greenblatt, supra note 63.

66 Id.

67 Id. Greenblatt interviewed me for the story too, and correctly quoted me as countering as follows:

George Washington University law professor Lawrence Cunningham cautions that float is an "inherent feature" of insurance, and it's not unusual to see lawsuits in which policyholders or claimants say an insurer or claims administrator acted in bad faith by delaying payment. Cunningham, who is also a Berkshire shareholder and has edited several editions of "The Essays of Warren Buffett," said Berkshire corporate culture rests on "unwavering commitment to integrity." He said it would be "antithetical for the company to jeopardize that reputation by wrongfully delaying or denying claims or acting in any way inconsistent with faithful administration and payment of claims."

68 Interested readers can find the email queries at the following link: http://media2.scrippsnationalnews.com/shns/Risky_Business/Berkshire_e mails/index.html [http://perma.cc/74DR-U2JQ]. 
inaccuracies in the story but, shortly thereafter, Scripps emailed Berkshire to say it stood by it. ${ }^{69}$ So two weeks later, Berkshire publicized a rebuttal, asserting "bias and lack of professionalism" in the report. ${ }^{70}$ Examples: the piece wrongly suggested Berkshire controlled the defense of an asbestos case when the corporate defendant did, incorrectly insinuated that Berkshire unreasonably resists settling cases by focusing on $100 \%$ of the amount a plaintiff sought rather than Berkshire's fractional share among multiple defendants, and credited critical comments of an insurance claims executive without appreciating potential bias from his involvement in disputes with Berkshire. ${ }^{71}$

Despite Berkshire's refutation, such allegations reach the public and resonate with it. It is one way corporate reputations are shaped. And the story continued to have legs. In January 2014, a lawyer from K\&L Gates collated the cases in a presentation to the American Bar Association. ${ }^{72}$ It is not obvious that Berkshire would have done better with a more traditional public relations department. After all, other

69 Press Release, Berkshire Hathaway Inc. (Oct. 31, 2013), http://www.berkshirehathaway.com/news/Oct3113.pdf [http://perma.cc/HT 42-VU6J].

70 Id.

71 Id. Berkshire stressed that its payments in this business for claims and claims-expenses exceeded $\$ 2.4$ billion annually and $\$ 20$ billion cumulatively. The press release references Berkshire's honoring its multipronged duties to policyholders, insurers and reinsurers for which it manages claims, regulators, and shareholders "who expect us to operate well above any minimum standards of practice for our business." Berkshire also noted winning respect from all such constituencies, and awards from peers and industry trade groups. Acknowledging that the run-off and legacy areas involve complex contested claims, Berkshire said these could not be reduced to sound bites though the piece had tried to do just that. Berkshire stressed that though it disfavors public comments on pending cases, it felt constrained to do so to defend against a report that seemed calculated to influence those cases.

72 John Sylvester, Policyholder Litigation Involving Claims Handling by Resolute Management Inc., AM. BAR Ass'N (Jan. 2014), http://www.americanbar.org/content/dam/aba/administrative/litigation/ma terials/2014_inscle_materials/written_materials/b14_2_policyholder_litigat ion_involving_claims.authcheckdam.pdf [https://perma.cc/HG7K-SYGH]. 
insurers such as AIG have also been accused of slow-pay and no-pay practices. ${ }^{73}$

But the interaction between Greenblatt and the company was partial, as the Berkshire executives reached by Greenblatt regarded their insurance business duties as more important than complete engagement with the reporter. A full-time professional who makes such engagement a top priority would have formulated a comprehensive assessment ahead of publication, contributing to shaping the original story. That preparation would have likely led to a better outcome for Berkshire than the thrust and parry that now defines the public record. Berkshire acts as if it is small, but it is a Goliath to reporters and readers alike.

Berkshire and several of its subsidiaries often also make for good political targets, as evidenced by a campaign launched against Clayton Homes on April 3, 2015 by Daniel Wagner and Mike Baker. ${ }^{74}$ Writing a piece sponsored by the Center for Public Integrity in The Seattle Times, they alleged that Clayton's sales team channeled buyers into dubious mortgages: customers were offered few or no alternative financing options, terms were seductive (including low downpayment requirements), defaults and foreclosures were high, and collection practices were aggressive, the authors asserted. ${ }^{75}$

73 See, e.g., Dean Starkman, AIG's Other Reputation: Some Customers Say the Insurance Giant Is Too Reluctant to Pay Up, WAsH. Post (Aug. 21, 2005), http://www.washingtonpost.com/wp-dyn/content/article/2005/08/20/ AR2005082000179.html [http://perma.cc/V4AF-W36K].

74 Daniel Wagner \& Mike Baker, Warren Buffett's Mobile Home Empire Preys on the Poor, CTR. FOR PUB. InTEGRITy (Apr. 6, 2015, 8:57 PM), http://www.publicintegrity.org/2015/04/03/17024/warren-buffettsmobile-home-empire-preys-poor [http://perma.cc/4FHN-CXFS].

75 Id. The piece called out its own key findings about Clayton Homes: using multiple corporate names to make buyers believe they are shopping around; lending at rates exceeding fifteen percent and adding significant fees; customers complaining of deception and predation via changes, pressure, and fees; and two former dealers saying headquarters pressured them into channeling customers to borrow from Clayton despite these problems. 
Clayton promptly issued a response disagreeing with every negative assertion in the piece. ${ }^{76}$ It stressed its policies of customer protection while acknowledging that, in a minority of cases such as the ones the writers portrayed, customers facing periodic life challenges have difficulty repaying loans and may face foreclosure. ${ }^{77}$ The authors responded with a point-by-point rebuttal. ${ }^{78}$ At the Berkshire annual shareholders' meeting five weeks later, Buffett also repudiated the piece and, again, one of the writers responded with continued skepticism. ${ }^{79}$

The real reasons behind the piece later emerged to be more political than first appeared. At the time of the report, Congress had begun debating regulations applicable to manufactured housing loans. ${ }^{80}$ After the financial crisis of 2008, the Dodd-Frank Act added disclosure and timing requirements to such loans bearing high interest rates,

76 Clayton Homes Statement on Mobile-Home Buyer Investigation, OMAHA WORLD-HERALD (Apr. 3, 2015), http://www.omaha.com/claytonhomes-statement-on-mobile-home-buyer-investigation/article_7052e0c4da3b-11e4-8abd-5f0b53380837.htmlda3b-11e4-8abd-5f0b53380837.html [http://perma.cc/HC9L-64DP].

77 Id.

78 Daniel Wagner \& Mike Baker, A Look at Berkshire Hathaway's Response to 'Mobile Home Trap' Investigation, CTR. FOR PuB. INTEGRITY (Apr. 7, 2015, 9:12 AM), http://www.publicintegrity.org/2015/04/06/17081/ look-berkshire-hathaways-response-mobile-home-trap-investigation [http://perma.cc/Y72J-VUYX].

79 Mike Baker, Buffett Sticks Up For Mobile-Home Business at Shareholder Meeting, SEATTLE TIMES (May 2, 2015), http://www. seattletimes.com/business/real-estate/buffett-sticks-up-for-mobile-homebusiness-at-shareholder-meeting/ [http://perma.cc/7Q3A-4CGY]. All the claims contradict everything Clayton Homes stands for, as I explained in both my book, Berkshire Beyond Buffett, and in a New York Times column several months before this piece-a column, incidentally, which Clayton Homes cited in its response and which the writers dismissed in rebuttal because it was written by me, whom they called "a longtime Buffett acolyte." Wagner \& Baker, supra note 78; Lawrence A. Cunningham, The Philosophy of Warren E. Buffett, N.Y. Times: DeALBook (May 1, 2015) http://www.nytimes.com/2015/05/02/business/dealbook/the-philosophy-ofwarren-e-buffett.html [http://perma.cc/CXT4-7S79].

80 See Preserving Access to Manufactured Housing Act of 2015, H.R. 650, 114th Cong. (2015). 
which Congress has been considering repealing as onerous and costly-a House vote was set for mid-April. ${ }^{81}$ Clayton and other industry leaders supported repeal while some homeowner and consumer groups were opposed. On one side, the manufactured housing trade association stressed the importance of unregulated access for lower income people to this kind of housing, while consumer advocates urged regulation to protect the impecunious from costly housing loans. ${ }^{82}$

Although the original report did not mention these points, the writers added the theme in a story in mid-May-linking their original assertions to Clayton's incentives in the political debate and making it clear that they were on the other side of that debate. ${ }^{83}$ Thus, it appears that the authors wrote a piece of political advocacy, not investigative journalism, and targeted Clayton based on ulterior motives, not as neutral reporters of facts. Notably, it was also revealed that one of the writers, Wagner, had an undisclosed conflict of interest: his sister was a lawyer representing plaintiffs in lawsuits against Clayton Homes. ${ }^{84}$

If Clayton's formal response and Buffett's oral comments had missed their mark, consideration should certainly be given to changing Berkshire's lean anti-bureaucratic model to add a department of political or public affairs at the

81 See id.; H.R. REP. No. 114-53, at 2-3 (2015).

82 Compare Jan Hollingsworth, Dodd-Frank and Manufactured Home Financing: The Place Where Good Intentions and Unintended Consequences Collide, Manufactured Home Living News (May 18, 2015), http://www.reuters.com/article/2015/05/18/idUSnGNX5smRmG+1c5+GNW 20150518 [http://perma.cc/SGW3-PWMK], with Zach Carter, House Republicans Hand Warren Buffett Big Win on Expensive Loans to the Poor, HuFFInGTON Post (Apr. 14, 2015), http://www.huffingtonpost.com/2015/ 04/14/manufactured-housing-republicans_n_7065810.html [http://perma. cc/VEW5-P8MR].

83 Mike Baker, Buffett's Mobile-Home Business Has Most to Gain From Deregulation Plan, SEATTLE Times (May 17, 2015), http://www. seattletimes.com/business/real-estate/buffetts-mobile-home-business-hasmost-to-gain-from-deregulation-plan [http://perma.cc/GQ3Y-R743].

84 Baker, supra note 79. 
subsidiary and/or parent levels. ${ }^{85}$ As with Greenblatt's NICO story, the reporters said they repeatedly tried to connect with Berkshire and Clayton personnel without success ${ }^{86}$ undoubtedly in part due to how Berkshire has no public relations personnel. Also, as with the NICO story, it may be more prudent for a company of Berkshire's scale and impact to maintain a dedicated professional to handle such investigative reporting, as distasteful as that may be to Buffett and others at Berkshire. ${ }^{87}$

Some Berkshire subsidiaries maintain their own coterie of public relations and lobbying professionals. Visit the web page of Berkshire Hathaway Energy, for example, and you will read of its involvement at the center of important national policy debates ranging from consumer energy prices to climate change. ${ }^{88}$ One proxy for the centrality of Berkshire to national energy policy is the series of shareholder proposals in recent years seeking to have Berkshire's board

85 See Cunningham, supra note 2, at 18.

86 Wagner \& Baker, supra note 78.

87 In Clayton's case, Wagner and Baker continued their campaign, publishing an incendiary piece the day after Christmas 2015 charging that Clayton's corporate culture is rabidly racist. See Mike Baker \& Dan Wagner, Minorities Exploited by Warren Buffett's Mobile Home Empire, SEATTle Times (Dec. 26, 2015), http://www.seattletimes.com/seattlenews/times-watchdog/minorities-exploited-by-warren-buffetts-mobilehome-empire-clayton-homes [http://perma.cc/7YZ2-5MMU]. Clayton promptly responded with a corporate press release repudiating all allegations. See Press Release, Clayton Homes, Reporting Mischaracterizes Clayton Homes' Treatment of Customers and Employees (Dec. 26, 2015), http://www.businesswire.com/news/home/20151226005 004/en/Reporting-Mischaracterizes-Clayton-Homes\%E2\%80\%99-Treatme nt-Customers-Employees [http://perma.cc/NX8Z-PEPY]. Several Democratic members of the U.S. House of Representatives Committee on Financial Services called for a federal investigation. See Letter from Rep. Maxine Waters et al. to Richard Cordray, Director, Consumer Financial Protection Bureau, and Hon. Loretta Lynch, Attorney General (Jan. 12, 2016), http://democrats.financialservices.house.gov/uploadedfiles/01.12. 2016_manufactured_housing_letter_final.pdf [http://perma.cc/B5PJ-2JCC].

88 See BERKSHIRE HATHAWAY ENERGY, https://www.berkshirehathaway energyco.com [http://perma.cc/9SCC-ALZ6]. 
set air quality goals for its utility businesses-such proposals were made in 2011, 2013, and 2014. ${ }^{89}$

Berkshire Hathaway Energy has grown to its present continental scale through acquisition, both before and since Berkshire's purchase of it, with each unit maintaining such departments, along with professionals who regularly engage in price-setting processes with local public utility authorities. ${ }^{90}$ The company and its subsidiaries engage in public debates and policy determinations in matters ranging from the construction of specific new coal-fired power plants to the national transition from fossil fuels to solar.

In such settings, the need for professional public relations and lobbying personnel is clear, as suggested by solar power debates in Nevada affecting Berkshire's local public utility, NV Energy. At issue is how much credit residential solar users get for electricity they generate for transmission back to the power grid. State law provided for aggregate credits up to three percent of the utility's historical peak load for such "net metering" credit. So long as state-wide solar generation was less than that, all solar users earned full credit; if the limit were exceeded, new solar users would not get the credit. Solar advocates sought to boost the cap, arguing it would soon be reached and stressing the need for economic incentives to sustain solarization; NV Energy resisted, forecasting reaching the cap much later and noting the need to avoid having those without solar panels pay more for energy than those with solar panels. ${ }^{91}$

89 Steve Jordon, Warren Watch: Buffett's 'German Scout' On the Hunt, OMAHA WORLD-HERALD (Mar. 22, 2015, 1:00 AM), http://www.omaha.com/ money/warren-watch-buffett-s-german-scout-on-the-hunt/article_92a927 bd-1a7f-5436-9cec-f02372c24fd6.html [http://perma.cc/GF4D-VAG9].

90 See Berkshire Hathaway Energy, Annual Report (Form 10-K), at 46, 70-75 (Mar. 2, 2015), https://www.berkshirehathawayenergyco.com/ assets/upload/financial-filing/20141231_99_bhe_annual.pdf [http://perma. cc/VSL8-VG2S] (discussing general corporate as well as unit-buy-unit regulatory matters).

91 Net Metering, NV ENERGY, https://www.nvenergy.com/renewables environment/renewablegenerations/NetMetering.cfm [http://perma.cc/QB T8-E97Y] (showing that NV Energy offered different rates to customers depending on time of use). See, e.g., Jim Wrathall, Nevada Solar Update: 
Both sides lobbied and engaged in public relations campaigns - and both were accused of overdoing it. At a public hearing on the issue, for example, lawmakers accused the solar industry of sending "aggressive" emails criticizing specific people, prompting a leading solar advocate to apologize publicly for his staff's work. ${ }^{92}$ The accusations against NV Energy went beyond that company to target Berkshire itself, especially Buffett, turning the local story into a David versus Goliath match shaded by assertions of overzealous capitalism, greed, and hypocrisy. One headline read that "Warren Buffett is sending mixed messages on green energy." 93 Contrasting Buffett's boasts of Berkshire investments in renewables with NV's position in the Nevada debate, one source cynically declared, "[i]t always comes down to money . . . even if it looks kind of hypocritical." 94

While editors may have liked the storyline pitting consumer-loving, tree-hugging do-gooders against the monopolistic profiteers at Berkshire, in fact, the duller reality was the complex and contestable public policy of

Senator Harry Reid Takes On Warren Buffett's Berkshire Hathaway in Net Metering Debate, Sullivan \& Worcester: Energy FIn. REPORT (Sept. 8, 2015, 8:00 AM), http://blog.sandw.com/energyfinancereport/2015/09/ nevada-solar-update-senator-harry-reid-takes-on-warren-buffets-berkshire -hathaway-in-net-metering-debate [http://perma.cc/EF5J-8BK8]; Herman K. Trabish, As Regulators Act, Nevada Net Metering Debate Takes Center Stage at Las Vegas Conference, UTILITY Dive (Aug. 31, 2015), http://www. utilitydive.com/news/as-regulators-act-nevada-net-metering-debate-takescenter-stage-at-las-veg/404799 [http://perma.cc/V4ZF-3WUP]; Krysti Shallenberger, Heated Debate in Nev. Over Solar Net Metering Settles Down, Governors' Wind EnERGy CoAL. (May 26, 2015), http://www.gov ernorswindenergycoalition.org/?p=13146 [https://perma.cc/M2LL-EW8D].

92 Reem Nasr, Ground Zero in the Solar Wars: Nevada, CNBC (May 26, 2015, 1:44 PM), http://www.cnbc.com/2015/05/26/ground-zero-in-thesolar-wars-nevada.html [http://perma.cc/HCT5-C2VC].

93 Mark Chediak, Noah Buhayar, \& Margaret Newkirk, Warren Buffett Is Sending Mixed Messages on Green Energy, BloomberG Bus. (May 18, 2015, 12:09 PM), http://www.bloomberg.com/news/articles/201505-18/berkshire-fights-rooftop-solar-as-buffett-champions-green-energy [http://perma.cc/G786-ZCTK].

94 Id. 
transitioning from fossil fuels to renewables. ${ }^{95}$ Berkshire has a dog in that fight and NV Energy is one of the many Berkshire Hathaway Energy subsidiaries actively engaged in the process. It would be absurd to believe, however, that energy scientists and business executives alone will define the dialogue and process everything that the energy company requires be said. For that, the company must have public relations specialists and lobbying professionals on staff.

More generally, while Berkshire has won plaudits for good corporate citizenship, ${ }^{96}$ some complain about the absence of conglomerate-wide reporting on social responsibility or sustainability. ${ }^{97}$ Berkshire's unusual structure does not lend itself to issuing a formal corporate report at the Berkshire level and most of the subsidiaries are essentially semi-private: given the parent's gargantuan size, all but a few subsidiaries are so small in relation to it that only limited disclosure is included about them in Berkshire's public filings. ${ }^{98}$ While all can indeed fend for themselves and

95 Reem Nasr of CNBC quoted me correctly as follows: "The question is how fast we should move as a society in transition from fossil fuels to renewables, because there will be a transition eventually. . . . Berkshire [executives] are capitalists who are interested in returns. . . . But at the same time, [Buffett] has scruples and the company has a conscience." Nasr, supra note 92.

96 E.g., Bos. Coll. Carroll Sch. Of MGmt., The Most Respected U.S. COMPANIES (2008), http://www.bcccc.net/_uploads/documents/live/Global Pulse2008.pdf?_hstc=166758561.28c25f3522ded499ee82095cf3ff99bd.144 7538430494.1447971346846.1448059856934.3\&_hssc $=166758561.1 .1448$ 059856934\&_hsfp=607606643 [http://perma.cc/9KQR-E9AC] (ranking Berkshire ninth out of 203 companies analyzed based on survey data of 20,000 people).

97 Elaine Cohen, Warren Buffett on Sustainability. Not., CSRREPORTING (June 12, 2010), http://csr-reporting.blogspot.com/2010/06/ warren-buffett-on-sustainability-not.html [http://perma.cc/6A8X-YKNZ].

98 See BerkshiRE HathaWAy INC., 2014 ANNUAL REPORT 125 (2015) http://www.berkshirehathaway.com/2014ar/2014ar.pdf [http://perma.cc/N8 EA-R6Z6] (showing total number of Berkshire employees as 340,499). Two large Berkshire subsidiaries, Berkshire Hathaway Energy and BNSF, have public debt outstanding and therefore file regular periodic reports with the Securities and Exchange Commission containing considerable 
there is some cost to having a centralized public relations function, creating an effective office need not be a splurge.

It would be simple enough to hire a single professional to oversee all the subsidiaries and to guard Berkshire's reputation from Omaha as needed. The cost would be modest and there would be scant imposition on subsidiary autonomy. On a related note, Berkshire likewise has no general counsel's office, and while that has generally not been a problem, it has occasionally failed to make legally required filings. ${ }^{99}$ While apparently not material, such lapses show poor corporate housekeeping. Such practices are not ones that any company should want and impose costs on the business. Correcting it would be relatively simple: hire a general counsel.

\section{E. Hypocrisy Charges and Uncertainty Due to Alter Ego}

Buffett kept a relatively low profile through most of his career. He became a celebrity only in the early 2000s. Although as Berkshire's public face he previously took positions on corporate topics-accounting, governance, and takeovers-at that point, he began to address general matters of national interest, including the hot button issues of taxes and wealth. But those topics tended to entwine Buffett's private life with Berkshire's future-especially its ownership structure-so they were uniquely suited for him to address. It presented a downside, however.

detail. Berkshire Hathaway Energy, Annual Report (Form 10-K) (Mar. 2, 2015) https://www.berkshirehathawayenergyco.com/assets/upload/finan cial-filing/20141231_99_bhe_annual.pdf [http://perma.cc/MR2P-M84V]; BNSF Railway, Annual Report (Form 10-K) (Mar. 2, 2015), http://www. bnsf.com/about-bnsf/financial-information/form-10-k-filings/pdf/10k-llc2014.pdf [http://perma.cc/UHE3-KADU].

99 David McLaughlin, Warren Buffett Agrees to Settlement After Violating Antitrust Laws, SYdney Morning Herald (Aug. 21, 2014), http://www.smh.com.au/business/warren-buffett-agrees-to-settlementafter-violating-antitrust-laws [http://perma.cc/S8LN-Y5MT]. Berkshire generally retains Munger, Tolles \& Olson LLP for legal work, which tends to involve corporate acquisitions and securities disclosure. 
People conflated Buffett's views on estate taxes, which he supported, with Berkshire's interest in acquiring family companies at discounts when owners faced such tax liabilities. That is especially costly considering how Berkshire itself is a microcosm of America-some of its subsidiaries were founded and run by deeply conservative families in Salt Lake City and Waco, others by progressives in Boston and Seattle. The company's businesses are managed by devout Christians, observant Jews, and practicing Mormons, as well as agnostics and atheists, Americans, Germans, and Israelis, totaling nearly 350,000 employees worldwide. ${ }^{100}$

Buffett's condemnation of the financial services industry has provoked both ire and charges of hypocrisy. One-third of Berkshire's $\$ 130$ billion investment portfolio is concentrated in financial intermediaries, including longstanding substantial positions in American Express and Wells Fargo, plus stakes in controversial institutions at the center of the 2008 financial crisis like Bank of America and Moody's. ${ }^{101}$ Yet Buffett lambasts banks and other financial intermediaries for both high fees and poor services. ${ }^{102}$

Similarly, as noted earlier, Buffett is a critic of private equity companies, yet partnered twice in recent years with private equity firm $3 \mathrm{G}$ in substantial acquisitions. ${ }^{103}$ The perceived wedge between word and deed and related criticism is longstanding. In the 1980s, Buffett chastised

100 Lawrence A. Cunningham, Big-Hearted Warren Buffett's Guide to Giving, CNBC (Dec. 5, 2014, 8:00 AM), http://www.cnbc.com/2014/12/05/ where-big-hearted-buffett-and-his-best-friend-disagree.html [http://perma. cc/777G-ZBPF].

101 See Berkshire Hathaway InC., 2014 Annual Report 17 (2015) http://www.berkshirehathaway.com/2014ar/2014ar.pdf [http://perma.cc/W4 L5-2CMM] (among total portfolio value of $\$ 117$ billion, listing American Express, Goldman Sachs, Moody's, U.S. Bancorp, and Wells Fargo, aggregating to $\$ 50$ billion).

102 The Essays of Warren Buffett, supra note 15, 169-74; see Anupreeta Das, Warren Buffett Has an Image Problem, Wall ST. J. (Nov. 12, 2015, 6:43 PM), http://www.wsj.com/articles/warren-buffett-has-animage-problem-1447371811 [http://perma.cc/MXH2-EQNQ].

103 See supra notes 52-57 and accompanying text. 
leveraged buyout operators, corporate raiders, and the bankers who charged vast fees to aid them; yet Berkshire owned a large stake in Salomon Brothers, which earned substantial profits by arranging debt financing and facilitating hostile takeovers. ${ }^{104}$ It is possible to square these positions-chosen companies are exceptions, distinguishing relative fees from blanket reproach, or contrast Buffett's personal views from Berkshire's corporate practices. But the disconnect remains a cost, one derived from the executive choice of public statements.

Buffett's and Berkshire's approaches to taxes present a similar disconnect that has posed related costs. For example, Buffett has said and written about the unfairness of the American tax code, famously saying his secretary pays more taxes than he does. ${ }^{105}$ Yet Berkshire defers taxes through lengthy holding periods, finds innumerable ways to minimize taxes and maximize tax credits, and pursues tax-advantaged transactions. Howls of hypocrisy result which, of course, confuse Buffett the individual with Berkshire the company ${ }^{106}$ as well as miss the difference between pure tax strategies and the broader investment values Berkshire has long adopted. ${ }^{107}$

Among tax-advantaged deals that could equally be explained by Berkshire's fundamental investment philosophy was its 2014 swap of long-time holdings in The

104 See Dale Arthur Oesterle, Revisiting the Anti-Takeover Fervor of the '80s Through the Letters of Warren Buffett: Current Acquisition Practice is Clogged by Legal Flotsam from the Decade, 19 CARDOZO L. REV. 565, 573-77 (1997).

105 See Warren E. Buffett, Stop Coddling the Super-Rich, N.Y. TIMES (Aug. 14, 2011), http://www.nytimes.com/2011/08/15/opinion/stop-coddlingthe-super-rich.html?_r=0 [http://perma.cc/2JVS-XSFQ]; Morris Propp, Warren Buffett's Nifty Tax Loophole, BARRON'S (Apr. 11, 2015), http://www.barrons.com/articles/warren-buffetts-nifty-tax-loophole1428726092\# [http://perma.cc/9ZLH-YRA8].

106 Propp, supra note 105; Tim Worstall, Warren Buffett's Very Strange Tax Argument, ForBes (Aug. 15, 2011), http://www.forbes.com/ sites/timworstall/2011/08/15/warren-buffetts-very-strange-tax-argument [http://perma.cc/Z2W4-B9R2].

107 See The Essays of WARren BuffetT, supra note 15, at 282-85. 
Washington Post Company (by then called Graham Holdings Company) for a television station; an outright sale of the stock would have triggered capital gains of some $\$ 400$ million. ${ }^{108}$ Or consider Berkshire's swap in 2015 of long-time holdings in Gillette (dating to the 1980s and eventually part of Procter \& Gamble) in exchange for the Duracell battery business, which included nearly $\$ 2$ billion in cash, yet was tax-deferred. Selling that stock for cash, given Berkshire's basis of $\$ 336$ million and a market value of $\$ 4.7$ billion, would have triggered a tax of $\$ 1.66$ billion. ${ }^{109}$ Despite tax advantages, all such transactions reflect Berkshire's longstanding fundamental values, which drive the decisions. ${ }^{110}$

Small companies might be the alter egos of their owners, as the Supreme Court held in the Hobby Lobby case, saying they have constitutional rights to the free exercise of religion. ${ }^{111}$ But large companies like Berkshire are not the dummies of their leaders and corporate decisions are not political statements. In running Berkshire, Buffett has a fiduciary duty. It requires him to make decisions based on

108 See Antoine Gara, Berkshire May Avoid \$400 Million Tax Bill in Graham Holdings Swap, THESTREeT (Mar. 14, 2014), http://www.the street.com/story/12529683/1/berkshire-may-avoid-400-million-tax-bill-ingraham-holdings-swap.html [http://perma.cc/XZQ8-RVLE].

109 See Allan Sloan, It's Not Hard to Close the Cash-Rich Split-Off Loophole, WASH. PosT (Jan. 21, 2015), https://www.washingtonpost.com/ business/economy/its-not-hard-to-close-the-cash-rich-split-off-loophole/20 15/01/21/87da04ae-9dcb-11e4-bcfb-059ec7a93ddc_story.html [https://per ma.cc/RP62-7LNM]; Steve Jordon, Stock-For-Company Duracell Deal Follows Berkshire Pattern, OMAHA WorLd-HERALD (Nov. 11, 2014, 1:00 AM), http://www.omaha.com/money/stock-for-company-duracell-deal-foll ows-berkshire-pattern/article_ea6cc45d-a97c-561e-9e36-fefd57991e9d.html [http://perma.cc/H983-8TJ8].

110 See Adam Shell, Buffett Snaps Up Duracell from P\&G, USA TODAY (Nov. 13, 2014, 7:50 AM), http://americasmarkets.usatoday.com/2014/ 11/13/buffett-snaps-up-duracell-from-pg [http://perma.cc/L6WX-FWEY] (quoting the author to the foregoing effect and adding the example of Berkshire's swap of a minority stake in Phillips 66 for all assets of a pipeline lubricant business).

111 See Burwell v. Hobby Lobby Stores, Inc., 134 S. Ct. 2751, 2785 (2014). 
what is best for Berkshire, not on whether they are consistent with his views on tax fairness or other political convictions. Given its size, it is no surprise that Berkshire shareholders are diverse politically and, while most concur with Berkshire policies and Buffett's business philosophy, they do not invariably agree with Buffett's political views. ${ }^{112}$

The alter ego phenomenon has produced both Berkshire's greatest value and ultimate cost: Buffett made the company great and his eventual departure raises questions about succession in a way that other executive succession plans do not. Berkshire cannot be replicated, and the man cannot be replaced. Critics say the company cannot survive without him. For example, The Economist wrote, as Buffett became an octogenarian, that Berkshire was down to "playing out the last hand," contending that in holding the contrary view, I am "too easily convinced . . .."113 Steven Davidoff Solomon in The New York Times lamented that Buffett graced Berkshire with an irreplaceable magic touch. ${ }^{114}$ At Berkshire's 2013 annual meeting, investor Douglas Kass asserted his belief that Berkshire is no more likely to survive without Buffett than Teledyne was without Henry Singleton. ${ }^{115}$

112 See Luciana Lopez, Where Shareholders Disagree with Buffett: Politics, REUTERs (May 4, 2015), http://blogs.reuters.com/talesfromthetrail/ 2015/05/04/where-shareholders-disagree-with-buffett-politics [http://per ma.cc/2HGL-5EB3].

113 See Berkshire Hathaway: Playing Out the Last Hand, ECONOMIST (Apr. 26, 2014), http://www.economist.com/news/briefing/21601240warren-buffetts-50-years-running-berkshire-hathaway-have-been-onebusinesss-most-impressive [http://perma.cc/94VX-BW67]; Berkshire Hathaway: The Post-Buffett World, Economist (Jan. 10, 2015), http:// www.economist.com/news/business-books-quarterly/21638099-successionbiggest-challenge-post-buffett-world [http://perma.cc/L3Z3-YMP8].

114 Steven Davidoff Solomon, With His Magic Touch, Buffett May Be Irreplaceable for Berkshire, N.Y. TIMES: DEALBOOK (May 21, 2013, 6:50 PM), http://dealbook.nytimes.com/2013/05/21/buffett-with-his-magic-touchmay-be-irreplaceable/ [http://perma.cc/74T7-LLGQ].

115 See Andrew Ross Sorkin, For Buffett, the Past Isn't Always Prologue, N.Y. Times: DealBook (May 6, 2013, 9:23 PM), http://dealbook.nytimes.com/2013/05/06/for-buffett-the-past-isnt-alwaysprologue/ [http://perma.cc/93E3-32RD]. 
If the critics are right, that is a huge cost. Even if they prove incorrect, the fact that such a perception is widely held is a modest cost.

\section{F. Miscellaneous: Public Family Firms and The Tenure Myth}

Certain problems and costs are not easy to classify and there may be costs other than those identified above that warrant attention. For one, as taught by the Dexter and Gen Re deals, using cash avoids amplifying the cost of mistaken acquisitions. While undoubtedly beneficial, this feature of the Berkshire model also presents a cost that manifests whenever paying stock would produce advantages in a transaction. That happens when the selling shareholders value stock more than cash. For example, where selling shareholders' tax basis is low, receiving shares defers significant taxes that would be due if sold for cash.

The cost to Berkshire of preferring paying in cash rather than stock is most acute in the context of targets that are publicly traded family businesses. Family businesses appeal to Berkshire as they often bring a sense of legacy and permanence that is central to the Berkshire business model. Many families prize Berkshire's commitments to autonomy and permanence, often selling to Berkshire for less than rival bids or intrinsic value. For family businesses owned solely by close-knit groups who all wish to sell to Berkshire, the cash preference at a discount creates no problems.

But problems arise for publicly traded family businesses. When directors of such companies sell control, they are dutybound to get the best value for shareholders. ${ }^{116}$ In a stock deal where all holders share gains in future business value, those directors could consider Berkshire's special culture in valuing the transaction. ${ }^{117}$ But with cash, all such future value goes to Berkshire's shareholders, not the target's

116 See Revlon, Inc. v. MacAndrews \& Forbes Holdings, Inc., 506 A.2d 173, 182 (Del. 1986).

117 See Paramount Communications, Inc. v. Time, Inc., 571 A.2d 1140, 1151 (Del. 1989). 
public stockholder, who would also gain nothing from the autonomy or permanence that family members prize in a sale to Berkshire. So target directors will resist an all-cash sale at a discount and seek rival suitors at higher prices, even stimulating an auction to drive price up-repelling Berkshire, which avoids auctions. ${ }^{118}$

An example can be drawn from Berkshire's 2003 acquisition of Clayton Homes, a publicly traded family business bought for a modest (seven percent) premium to market. Many Clayton shareholders objected; one, Cerberus Capital Management, told Clayton it wanted the chance to make a competing bid; another sued. ${ }^{119}$ The result was a sixmonth delay in getting to a shareholder vote, which narrowly approved the Berkshire deal. ${ }^{120}$

Many Clayton shareholders were disappointed, but Cerberus opted not to outbid Berkshire, and the court dismissed the lawsuit. ${ }^{121}$ The scenario remains unattractive to Berkshire, however, given the risk of litigation, delay, and rival bids. Under Berkshire's acute aversion to bidding in any auction, the risk of an auction would be enough to deter Berkshire from bidding at all. The upshot: the publicly traded family business is outside Berkshire's acquisition model, amounting to an opportunity cost for what would otherwise be a sweet spot.

118 Letter from Warren E. Buffett, Chairman, Berkshire Hathaway, Inc., to Shareholders of Berkshire Hathaway, Inc. (Feb. 27, 2015), http://www.berkshirehathaway.com/letters/2014ltr.pdf [http://perma.cc/M94G-YE9F] ("We don't participate in auctions.").

119 See Denver Area Meat Cutters \& Emp'rs Pension Plan v. Clayton, 209 S.W.3d 584 (Tenn. Ct. App. 2006); Denver Area Meat Cutters v. Clayton, 120 S.W.3d 841 (Tenn. Ct. App. 2003).

120 Andrew Ross Sorkin, Buffett Wins Battle to Buy Clayton Homes, N.Y. Times (July 31, 2003), http://www.nytimes.com/2003/07/31/business/ buffett-wins-battle-to-buy-clayton-homes.html [http://perma.cc/XN3RX2F9].

121 See Cunningham, Berkshire Beyond Buffett, supra note 6, at $61-62$. 
Another miscellaneous cost category concerns the myth of the permanent manager at Berkshire. ${ }^{122}$ Berkshire prides itself on the long tenure of its senior managers. But besides highly-publicized departures such as those described earlier, there are numerous quieter ones. In each of a dozen cases, the frustrating fact is opacity about causes or resolutions. Berkshire offers little or nothing by way of commentary and the executives are mum, perhaps owing to contractual commitments in severance agreements or, more likely, in light of Berkshire culture, out of a sense of loyalty.

Some low-key executive departures include the following. In the 1990s, Fechheimer Brothers Co., a uniform maker, had a series of presidents, including Richard Bentley, promoted from Scott Fetzer. In 1998, Bentley resigned from Fechheimer without comment by him or Berkshire. He was succeeded by Patrick Byrne, who stayed just two years. ${ }^{123}$ In 2003, Sheila O'Connell Cooper, chief executive of Pampered Chef, Ltd., left after five months on the job without a trace. $^{124}$ In 2006, Barry Tatelman withdrew from management of Jordan's Furniture to embark on a career in the arts, leaving his brother Eliot in charge. ${ }^{125}$

In 2007, soon after Sokol joined the board of Johns Manville, its CEO Steven B. Hochhauser was replaced by a MidAmerican Energy colleague, Todd M. Raba, who stayed only until 2012. ${ }^{126}$ Finally, in 2012, Larson-Juhl's long-time

122 See Robert P. Miles, The Warren Buffett CEO: Secrets From The Berkshire Hathaway Managers 357-58 (2003).

123 Geert De Lombaerde, Fechheimer President Exits, Cincinnati Bus. COURIER (May 16, 1998), http://www.bizjournals.com/cincinnati/stories/ 1998/03/16/story5.html [http://perma.cc/AH87-7QWK]; ANDREW Kilpatrick, Of Permanent Value: The Story of Warren Buffett 438 (2011).

124 See Karen Linder, The Women of Berkshire HathaWAY: Lessons FROM WARREN BuFFETT's FEMALE CEOs AND DiRECTORs 93 (2012).

125 Keith Reed, Bowing Out at Jordan's, Bos. GLOBE (Dec. 22, 2006), http://www.boston.com/business/articles/2006/12/22/bowing_out_at_jordan s/ [http://perma.cc/A7VH-Z2FJ].

126 Vanessa Small, New at the Top, WASH. Post (Oct. 27, 2013), https://www.washingtonpost.com/business/economy/new-at-the-top-tomeet-warren-buffett-this-outdoorsman-didnt-stay-lost-in-the- 
chief Steve McKenzie was replaced by Drew Van Pelt, newlyminted Harvard MBA, who had no experience in the industry. Apparently, Van Pelt was a choice of Tracy Britt Cool (who subsequently became chief executive of Pampered Chef). ${ }^{127}$

\section{G. Coda: Partnership Manqué}

Berkshire annual meetings once drew a few hundred people who, along with Buffett, owned a decisive majority of the stock. They felt the genuine bonds of a true partnership. Today, the meeting draws more than 40,000 out of nearly one million shareholders. Buffett's interest is now down to a third, and the inner core group's holdings are unlikely to exceed a majority. Buffett continues to talk about Berkshire having a corporate form with a partnership attitude. But it is only an attitude and it no longer genuinely reflects a true partnership.

The shareholders have signaled surprisingly close to unanimity on dividend policy. ${ }^{128}$ But discussions with shareholders indicate a greater division of opinion. ${ }^{129}$ You can expect once Buffett leaves the scene that some shareholders will become active in seeking policy changes, including some touching on the Berkshire model. While the dividend policy remains a plus without a cost, the disagreements over it might be classified as a cost. It arises from the broader costs of a shareholder body that has grown

woods/2013/10/27/924ffe10-3d83-11e3-b6a9-da62c264f40e_story.html [https://perma.cc/5VXH-7SLM].

127 See Cunningham, Berkshire Beyond Buffett, supra note 6, at 193-94.

128 Conversations From the BuffetT Essays Symposium 24-25 (Lawrence A. Cunningham ed., forthcoming 2016) (Buffett exchange with Cunningham indicating results of an early 1990s precatory Berkshire shareholder resolution overwhelmingly supporting Berkshire's dividend policy); THE ESSAYS OF WARREN BUFFETT, supra note 15, at 198 (reporting results of a 2013 precatory shareholder resolution on Berkshire dividend policy with $98 \%$ of the shares voting favoring the no dividend policy).

129 See Cunningham, Berkshire Beyond Buffett, supra note 6, at 208. 
through major stock-based acquisitions, including Gen Re and especially BNSF, as well as Dexter, Dairy Queen, and others. Ultimately, as with all other costs of the Berkshire model, it emanates from principle number one, which is conceiving of the corporation as a partnership.

\section{IMPLICATIONS FOR PEERS AND POLICY}

Beyond the important upshot of this analysis for Berkshire Hathaway are lessons for policymakers and others. The Berkshire model successfully emerged despite bucking five powerful trends affecting the rest of corporate America that cut in the opposite direction. These are: the rise of the independent director and monitoring board; the decline of executive power; the elevation of internal controls to a first-order policy option; the eclipse of the conglomerate form; and the proliferation of shareholder activism and hostile takeovers. The Berkshire model's success strengthens the case against these features and their rigidity. As with the previous Part, this one opens with a chart depicting highlights, here comparing five major issues that distinguish Berkshire from prevailing practice in corporate America, along with the important implications of the contrast.

Table 2: Value of Berkshire's Practices vs. Corporate America

\begin{tabular}{|l|l|l|l|}
\hline \multicolumn{1}{|c|}{ ISSUE } & $\begin{array}{l}\text { BERKSHIRE } \\
\text { PRACTICE }\end{array}$ & \multicolumn{1}{|c|}{$\begin{array}{c}\text { CORPORATE } \\
\text { AMERICA }\end{array}$} & \multicolumn{1}{|c|}{ LESSON } \\
\hline $\begin{array}{l}\text { A.1 } \\
\text { Governance: } \\
\text { Board Role }\end{array}$ & $\begin{array}{l}\text { Advisory: } \\
\text { board is } \\
\text { supportive } \\
\text { advisory body } \\
\text { there to help } \\
\text { the CEO }\end{array}$ & $\begin{array}{l}\text { Monitoring: } \\
\text { numerous forces } \\
\text { in recent decades } \\
\text { have transformed } \\
\text { boards into } \\
\text { interventionist } \\
\text { overseers and } \\
\text { supervisors of } \\
\text { executives }\end{array}$ & $\begin{array}{l}\text { Champion } \\
\text { flexibility in } \\
\text { governance } \\
\text { design to allow } \\
\text { for different } \\
\text { board types and } \\
\text { roles }\end{array}$ \\
& &
\end{tabular}




\begin{tabular}{|c|c|c|c|}
\hline ISSUE & $\begin{array}{l}\text { BERKSHIRE } \\
\text { PRACTICE }\end{array}$ & $\begin{array}{c}\text { CORPORATE } \\
\text { AMERICA }\end{array}$ & LESSON \\
\hline $\begin{array}{l}\text { A.2 } \\
\text { Governance: } \\
\text { CEO Power }\end{array}$ & $\begin{array}{l}\text { Consolidated: } \\
\text { CEO wields } \\
\text { near-total } \\
\text { corporate } \\
\text { power }\end{array}$ & $\begin{array}{l}\text { Neutralized: } \\
\text { numerous forces } \\
\text { in recent decades } \\
\text { have operated to } \\
\text { reduce or check } \\
\text { CEO power }\end{array}$ & $\begin{array}{l}\text { Appreciate that } \\
\text { sometimes } \\
\text { strong CEOs are } \\
\text { far more } \\
\text { desirable than } \\
\text { weak CEOs }\end{array}$ \\
\hline A.3 Culture & $\begin{array}{l}\text { Trust: relies } \\
\text { heavily on a } \\
\text { culture } \\
\text { mutual trust } \\
\text { and loyalty to } \\
\text { promote } \\
\text { desirable } \\
\text { behavior }\end{array}$ & $\begin{array}{l}\text { Control: numerous } \\
\text { forces in recent } \\
\text { decades have led } \\
\text { to corporations } \\
\text { adopting } \\
\text { abundant internal } \\
\text { controls to shape } \\
\text { behavior }\end{array}$ & $\begin{array}{l}\text { Stress that trust } \\
\text { and loyalty are } \\
\text { often far more } \\
\text { valuable } \\
\text { motivators than } \\
\text { controls }\end{array}$ \\
\hline $\begin{array}{l}\text { B. } \\
\text { Conglomer- } \\
\text { ate Form }\end{array}$ & $\begin{array}{l}\text { Epitome: dem- } \\
\text { onstrates enor- } \\
\text { mous success } \\
\text { that can be } \\
\text { obtained from } \\
\text { well-defined } \\
\text { conglomerate } \\
\text { structure }\end{array}$ & $\begin{array}{l}\text { Eclipsed: fallen } \\
\text { from favor but } \\
\text { pockets of success } \\
\text { remain }\end{array}$ & $\begin{array}{l}\text { Keep an open } \\
\text { mind about the } \\
\text { possible } \\
\text { optimality of the } \\
\text { conglomerate } \\
\text { form for some } \\
\text { firms }\end{array}$ \\
\hline $\begin{array}{l}\text { C. Hostile / } \\
\text { Activist } \\
\text { Takeovers }\end{array}$ & $\begin{array}{l}\text { Shunned: has } \\
\text { never made } \\
\text { hostile } \\
\text { takeovers or } \\
\text { exhibited } \\
\text { activist } \\
\text { tendencies and } \\
\text { would do well } \\
\text { to assure itself } \\
\text { strong defenses } \\
\text { against such } \\
\text { assaults }\end{array}$ & $\begin{array}{l}\text { Pervasive } \\
\text { Welcomed Threat: } \\
\text { seen as important } \\
\text { tool of corporate } \\
\text { governance and } \\
\text { widely applied } \\
\text { with mixed results }\end{array}$ & $\begin{array}{l}\text { Remain } \\
\text { solicitous } \\
\text { takeover } \\
\text { defenses } \\
\text { cautious and } \\
\text { exuberant } \\
\text { activism }\end{array}$ \\
\hline
\end{tabular}




\section{A. Governance and Culture}

The most general implication of Berkshire's model for public policy is to preserve the possibility for variation in governance design and business structure. This implication spans many topics, including the character and duties of the board of directors, the strength of corporate chief executives, and the degree of organizational direction harnessed by trust versus control. American policies on all such topics have taken directions during the past thirty years that are the opposite of the direction Berkshire has taken.

\section{Board Role}

During the latter half of Berkshire's rise to prominence, boards of American companies shifted from the advisory model to the monitoring model as people from multiple vantage points heralded the outside director as the solution to governance challenges. ${ }^{130}$ The rise of independent directors displaced the importance of expertise and obscured the traits Berkshire boasts in its directors, especially ownerorientation, understanding of business, and commitment to Berkshire's prosperity. These policy paths were driven largely by periodic needs to quell political disputes or respond to crises. The appeal to independence helped generate consensus while devaluing expertise. ${ }^{131}$

Director independence remains a valued characteristic in corporate governance, but expertise is making a comeback. Thus, the Sarbanes-Oxley Act all but requires financial expertise on the board, ${ }^{132}$ and the Dodd-Frank Act

130 Lawrence A. Cunningham, Rediscovering Board Expertise: Legal Implications of the Empirical Literature, 77 U. CIN. L. REV. 465, 469-70 (2008).

131 See generally Stephen M. Bainbridge, A Critique of the NYSE's Director Independence Listing Standards, 30 SEC. REG. L.J. 370, 381 (2002).

132 See Sarbanes-Oxley Act of 2002, Pub. L. No. 107-204, 116 Stat. 745 (2002) (codified at 15 U.S.C. §§ 7201-66 (2012)); 17 C.F.R. § 229.407(d)(5) (2014) (Item 407(d)(5) of Regulation S-K); 17 C.F.R. § 240.10a-3 (2014) (SEC Rule 10A-3). 
contemplates a similar approach to compensation committees. ${ }^{133}$ As my colleague and now Securities and Exchange Commission Commissioner Lisa Fairfax has explained, there is a case for the inside director, even if an uneasy one. ${ }^{134}$ The Berkshire model proves both the value of expertise and the value of having some deliberative body available to handle crises (e.g., the Sokol-Lubrizol affair ${ }^{135}$ ) and to steer the business during transitions (Buffett is relying heavily on the Berkshire board to assure continuity after he leaves the scene). ${ }^{136}$ The Berkshire model suggests that there are both reasons to have a board and reasons to oppose its primacy. ${ }^{137}$ Berkshire shows that a corporation can thrive with an advisory board of the old-fashioned model.

\section{CEO Power}

Before the 1990s, CEOs wielded substantial power, selecting the directors and enjoying the latitude that comes with deferential or passive shareholders. The rise of the independent board and of shareholder activism changed this dynamic, as boards and owners gained influence and exercised it to curtail executive power. The long-term effects of such a shift are yet to crystalize, but are likely to be

133 See Dodd-Frank Wall Street Reform and Consumer Protection Act, Pub. L. No. 111-203 § 952, 124 Stat. 1376, 1900-03 (2010) (codified at 15 U.S.C. § 78j-3 (2012)); 17 C.F.R. § 240.10c-1 (2014) (SEC Rule 10c-l).

134 Lisa M. Fairfax, The Uneasy Case for the Inside Director, 96 IowA L. REV. 127 (2010).

135 See supra note 27 and accompanying text.

136 See The Essays of WARREN Buffett, supra note 15, at 296 (discussing Berkshire's future and stressing that Berkshire has "an extraordinarily knowledgeable and business-oriented board of directors ready to carry out [its] promise of partnership").

137 Compare Kelli A. Alces, Beyond the Board of Directors, 46 WAKE Forest L. REV. 783, 783-84 (2011) (arguing for the abolition of the corporate board as anachronistic), with Stephen M. Bainbridge, Director Primacy: The Means and Ends of Corporate Governance, 97 Nw. U. L. REV. 547, 550 (2003) (arguing that the corporate board should wield considerable power at the apex of the corporate hierarchy). 
sweeping. ${ }^{138}$ The Berkshire model is a reminder of the value of executive power and a cautionary note about such broad scale change. Indeed, in his role as chief executive, Buffett has avoided the trap of other icons, who may be prone to vanity or licentiousness, proving that such flaws are not inevitable. ${ }^{139}$ Berkshire's plan to divide Buffett's historical roles as chairman and chief executive between two individuals shows the appeal of governance design flexibility for different contexts-uniting the roles is best during Buffett's tenure but dividing them seems better postBuffett. ${ }^{140}$

\section{Control Versus Trust}

Over the past four decades, corporate internal controls became a first-order policy option to respond to a wide variety of national problems, from financial fraud to terrorist financing. ${ }^{141}$ Despite their proliferation as regulatory tools to address issues ranging from consumer price gouging to worker safety and environmental protection, it is difficult to evaluate whether controls work and are worth their considerable cost. ${ }^{142}$

Corporate controls began as internal processes with positive aspirations of helping a corporation meet its objectives, a conception creating modest expectations of

138 See Marcel Kahan \& Edward Rock, Embattled CEOs, 88 TEx. L. REV. 987, 1041 (2010) (cataloging dozens of profound implications ranging from regulatory backlash to international corporate convergence).

139 See Tom C.W. Lin, The Corporate Governance of Iconic Executives, 87 Notre Dame L. REv. 351, 366-67, 375 (2011) (suggesting that iconic CEOs win too much organizational and legal deference (citing Steve Jobs), are prone to overconfidence (citing Buffett) and even licentiousness (citing Michael Eisner)).

140 See supra note 6 and accompanying text.

141 See Lawrence A. Cunningham, The Appeal and Limits of Internal Controls to Fight Fraud, Terrorism, Other Ills, 29 J. CoRP. L. 267, 268 (2004).

142 See generally Michael Power, The Audit Society: Rituals of VERIFICATION (1999) (describing the complexity and high cost of auditing regimes). 
results. When used as a leading policy option, however, controls assume a negative character. They become processes designed to prevent certain undesired events from occurring, a conception doomed to disappointed expectations. Controls are inherently limited in what they can do, making the modest expectations associated with positive aspirational controls sensible but increasing the likelihood of disappointed expectations associated with the more ambitious efforts of negative preventive controls.

Systemic forces make controls an attractive policy option. The rise of the board monitoring model played an important role, as controls dovetailed with such oversight. ${ }^{143}$ Movements for deregulation and cooperative compliance made controls appealing as alternatives to direct regulation. Resistance to federal preemption of state law makes controls an attractive way to inject federal policy into corporate affairs. The corporate social responsibility movement demands greater accountability; controls addressing interests of particular constituencies seem tailor-made for the purpose. An entire compliance industry arose, led by auditors and lawyers who developed expertise in the design, implementation, and testing of controls.

Yet these forces often resulted in controls that appear to work and can be audited rather than controls that work in fact. ${ }^{144}$ The result: corporate America tends to expect far more from internal controls than such systems can deliver. The Berkshire experience, using minimalist controls in favor of heavy reliance on trust, demonstrates that controls are not necessary to promote compliance or other desirable outcomes. Policymakers should be willing to tolerate more trust-based corporate cultures than the prevailing climate favoring control permits. But even Berkshire maintains a

143 See Melvin A. Eisenberg, The Board of Directors and Internal Control, 19 CARDOZO L. REV. 237, 238-39 (1997).

144 See Kimberly D. Krawiec, Cosmetic Compliance and the Failure of Negotiated Governance, 81 WASH. U. L.Q. 487 (2003). 
system of internal control over financial reporting because, as Buffett joked, "no sense being a damned fool."145

Still, the overwhelming principles of corporate governance and culture at Berkshire Hathaway are responsibility and trust. Such a model stands in sharp contrast to prevailing views among theorists and norms among practitioners. ${ }^{146}$ The theorists assume pervasive agency costs-managers acting with self-interest in derogation of owner interests - and many managers do in fact exhibit such behavior. ${ }^{147}$ Yet not all do, and Berkshire has a whole cadre of managers operating in the opposite manner. David F. Larcker and Brian Tayan of Stanford University summed up the implications with a poignancy and a question: "The operating principles of Berkshire Hathaway are in stark contrast to the 'best practices' recommended by governance experts. What does this say about the reliability of those best practices?" 148

\section{B. The Conglomerate Form}

Despite Berkshire's blemishes, the company avoided the major pitfalls of its form of business organization-the conglomerate, which was fashionable when Buffett began running Berkshire in 1965 but gradually and steadily faded from fashion while Berkshire prospered and perfected the model.

145 Letter from Warren E. Buffett, Chairman, Berkshire Hathaway, Inc., to Shareholders of Berkshire Hathaway, Inc. (Feb. 27, 2015), http://www.berkshirehathaway.com/letters/2014ltr.pdf [http://perma.cc/M9 4G-YE9F].

146 See Eisenberg, supra note 143, at 250.

147 See James P. Holdcroft, Jr. \& Jonathan R. Macey, Flexibility in Determining the Role of the Board of Directors in the Age of Information, 19 CARdozo L. REV. 291, 296 (1997).

148 David F. Larcker \& Brian Tayan, Berkshire Hathaway: The Role of Trust in Governance (Stanford Graduate Sch. of Bus. Closer Look Series, May 28, 2010), https://www.gsb.stanford.edu/sites/gsb/files/publicationpdf/cgri-closer-look-02-berkshire-hathaway.pdf [https://perma.cc/SP26$\mathrm{AUQR}]$. 
In the 1960s and 1970s, the conglomerate form of business organization flourished in corporate America, in part due to enactment in 1950 of the Celler-Kefauver Act, which discouraged mergers among rivals, stimulating acquisitions of unrelated businesses. ${ }^{149}$ Massive companies were built through numerous diverse acquisitions by powerful chief executives. One prominent example is ITT Corporation which, under the leadership of Harold Geneen and later Rand Araskog, boasted 350 different companies, including baking, car rentals, hotels, and insurance. ${ }^{150}$ Another example is Teledyne Technologies, Inc., assembled by Henry Singleton as nearly 100 different businesses encompassing acoustic speakers, aeronautics, banking, computers, engines, and insurance. ${ }^{151}$ By 1980 , the majority of Fortune 500 companies were conglomerates. ${ }^{152}$ Rationales included exploiting scale, seizing synergies, spreading managerial acumen, and diversifying investments.

But critics perceived indulgent empire building by imperious executives as many of these businesses struggled, incurred significant losses for sustained periods, misallocated capital internally, or otherwise proved difficult to manage. ${ }^{153}$ Under pressure from hostile corporate

149 See Sanjai Bhagat, Andrei Shleifer \& Robert W. Vishny, Hostile Takeovers in the 1980s: The Return to Corporate Specialization, Brookings PAPERS ON ECON. ACTIVITY: Microeconomics 55-56 (1990), http://scholar.harvard.edu/files/shleifer/files/hostile_takeovers_80s.pdf?m= 1360042383 [http://perma.cc/T63S-BA6S].

150 See generally ROBERT SOBEL, ITT: THE MANAGEMENT OF OPPORTUNITY ( $2 \mathrm{~d}$ ed. 2000) (documenting the multiple companies that ITT invested in at various points).

151 See generally George A. Roberts with Robert J. McVicker, Distant Force: A Memoir of the Teledyne Corporation and the MaN Who CREaTed IT (2007) (documenting the multiple companies that Teledyne invested in).

152 Gerald F. Davis et al., The Decline and Fall of the Conglomerate Firm in the 1980s: The Deinstitutionalization of an Organizational Form, 59 AM. Soc. REV. 547, 553 (1995).

153 The Essays of WARREn BuffetT, supra note 15, at 287 (discussing Buffett's account of the poor reputation of the conglomerate business model and how the Berkshire model differs). 
takeover artists seeking to maximize shareholder value as well as academics urging greater focus, the conglomerate model began to unravel. Raiders such as Carl Icahn and Ronald Perelman and buyout firms such as Kohlberg Kravis Roberts targeted or acquired conglomerates and proceeded to break them up while others, like ITT and Teledyne, simply succumbed to the changing times and divided into multiple discrete corporations. ${ }^{154}$

By 1990, the era of the conglomerates was over, and widely viewed as a systemic mistake. Top executives prone to conglomerate-wide systems and micromanagement ultimately undermined operational success. Subsidiary managers could execute more effectively when permitted to apply systems tailored to the needs of their business and focused on areas within their unique expertise. Boards of directors, increasingly called upon as active monitors of managers rather than loyal advisors, could not oversee sprawling empires. Shareholders could diversify for themselves more efficiently than conglomerate executives who proved inept at allocating capital. And U.S. antitrust policy had swung back in the direction of solicitude toward mergers among rivals. ${ }^{155}$

During this same period, however, Berkshire transformed itself from a small investment partnership in the 1960s into a diversified conglomerate with vast stock holdings by 1995 . Today, it is a conglomerate more sprawling than ITT, Teledyne, or any of the other colossuses of the 1980s, such as Beatrice, Gulf \& Western, Litton, or Textron. And its performance is peerless. One broad reason for this success is that Berkshire recognized and avoided all the pitfalls: Buffett, as chief executive, is the opposite of a micromanager; Berkshire's decentralization and principle of managerial

154 See George P. Baker \& George David Smith, The New Financial Capitalists: Kohlberg Kravis Roberts and the Creation of Corporate VALUE 168 (1998) ("The documented behavior of successful conglomerates shows that they tended to be opportunistic buyers but reluctant sellers of companies. So long as constituent business units continued to meet minimal corporate performance criteria, they were unlikely to be sold.”).

155 See Davis et al., supra note 152, at 554. 
autonomy enables managerial focus; Buffett's investment acumen made Berkshire's practice of diversification valuable to investors; and Berkshire's internal capital allocation saved stockholders sizable transaction costs and taxes.

Berkshire was not the only conglomerate to prosper amid the anti-conglomerate environment of recent decades. Several other thriving conglomerates stand out among widely-held public companies. A venerable case is General Electric, whose divisions span aviation, energy management, jet engines, light bulbs, and water. Despite a recent downsizing to focus more on industrial businesses-divesting its appliances, capital, and real estate businesses-the moves were not anti-conglomerate, but were instead a divestiture of businesses not meeting minimum profit thresholds, ${ }^{156}$ and the banking business had become newly regulated by Dodd-Frank. ${ }^{157}$ In fact, the company remained committed to potential acquisitions that would sustain the conglomerate model. ${ }^{158}$ Another example is United Technologies, a lower-profile company operating a diverse group of iconic brands such as Carrier air conditioning, Otis elevator, Pratt \& Whitney engines, and Sikorsky helicopters. ${ }^{159}$

156 See Ted Mann \& Erin McCarthy, GE Plans to Divest More Businesses; Profit, Revenue Decline, Wall ST. J. (Apr. 17, 2014, 4:31 PM), http:/www.wsj.com/articles/SB100014240527023036268045795053815994 50134 [http://perma.cc/Z7N4-X4FW].

157 JoAnn S. Lublin et al., GE Seeks Exit from Banking Business, WALL ST. J. (Apr. 10, 2015, 6:31 PM), http://www.wsj.com/articles/geprepared-to-exit-the-bulk-of-ge-capital-1428662109 [http://perma.cc/U28W -75R7]; Justin Fox, Is GE Capital A Dodd-Frank Victim?, BLOOMBERGVIEW (Apr. 10, 2015, 2:50 PM), http://www.bloombergview.com/articles/2015-0410/ge-blazes-a-path-for-the-financial-giants-to-follow [http://perma.cc/MV F6-S2FM].

158 See Mann \& McCarthy, supra note 156.

159 See Our Businesses At A Glance, United Technologies, http://www.utc.com/Our-Businesses/Pages/At-A-Glance.aspx [http://perma. cc/UR9K-CJX2]. Yet another example is Honeywell International Inc. See Ted Mann, Conglomerate Honeywell Finds Love Amid the Breakups, WALL ST. J. (Sept. 2, 2015, 12:53 AM), http://www.wsj.com/articles/conglomeratehoneywell-finds-love-amid-the-breakups-1441156184 [http://perma.cc/4C 7S-5STK]. 
Conglomerates also continue to flourish among closelyheld companies or public companies with controlling shareholders. An example of the latter is Danaher Corporation, a Fortune 500 company run by Mitchell and Steven Rales operating in numerous sectors, including dental equipment, life sciences, environmental technologies, industrial tools, and precision instruments. Among closelyheld conglomerates, an exemplar is the Marmon Group, a classic and massive conglomerate built by Jay and Bob Pritzker during the conglomerate boom and afterwards-and acquired by Berkshire in 2006.

Today, an entire sector is reviving the conglomerate model, led by technology behemoths such as Amazon, Facebook, and Google. The movement is epitomized by the conscious decision of Google to reorganize as Alphabet Inc. to arrange the growing diversity of its businesses. ${ }^{160}$ Generating abundant cash from its primary search business, Google has expanded into many fields, although they pivot around highly-innovative technology: Android, Chrome, Nest, YouTube, and the driverless car business. Google is consciously mimicking Berkshire in adopting an autonomous, decentralized, and trust-based organizational model, and its origins resemble those of General Electric. A century ago, GE's leadership viewed electricity the way Google's leadership sees technology: as a transformative force driving pervasive change in commerce, education, home life, and society at large. ${ }^{161}$

160 Compare Tim Mullaney, The True Mastermind of Google's Alphabet? Warren Buffett, MARkeTWATch (Aug. 17, 2015, 6:01 AM), http://www.marketwatch.com/story/the-true-mastermind-of-googlesalphabet-warren-buffett-2015-08-17 [http://perma.cc/FJ4X-62MH], with Max Nisen, No, Google's New Alphabet Structure is Really Nothing Like Berkshire Hathaway, QUARTZ (Aug. 13, 2015), http://qz.com/477284/nogoogles-new-alphabet-structure-is-really-nothing-like-berkshire-hathaway/ [http://perma.cc/2WM8-XQAT].

161 See Steve Jordon, Are Conglomerates Making a Comeback? Berkshire Hathaway's Business Model May Be Back in Fashion, OмAHA WORLD-HERALD (Aug. 21, 2015, 12:30 AM), http://www.omaha.com/money/ are-conglomerates-making-a-comeback-berkshire-hathaway-s-business- 
Berkshire-along with such companies as Danaher, General Electric, and United Technologies-proved that the conglomerate model can succeed when based on principles such as autonomy and permanence-the practice of acquiring diverse high-quality businesses and then nurturing and retaining them through thick and thin. Google-along with the likes of Amazon and Facebook-has the opportunity to extend the proof and the lessons. The lesson from Berkshire for such emulators is not only that the model can work, but to expose some of the challenges and blemishes that must be either addressed or tolerated.

\section{Activism, Hostility, and Defense}

Long before the era of the conglomerate, during the period examined in the classic text by Berle and Means, corporations were thought of as perpetual-enduring institutions such as Berkshire. ${ }^{162}$ But as the conglomerate era was eclipsed by the takeover era, corporations became more transient, in perception and fact. ${ }^{163}$ Transience is today's prevailing mindset too, sustained by those committed to pressuring corporations to deliver immediate shareholder results, whether it is shareholder activists, hedge funds, or private equity firms. The latter approach acquisitions very differently than Berkshire: they are highly leveraged, deeply interventionist, heavily intermediated, and short-term by design. ${ }^{164}$

Conglomerates, therefore, remain out of fashion, primed to attract hostility requiring strong defenses. While the best defense is solid and sustained economic performance, another advantage—shared by Berkshire as well as Danaher

model/article_a98b99a2-acca-5a89-9108-470d46a3fca8.html [http://perma. cc/2UGE-BQHM].

162 See Gerald F. Davis, The Twilight of the Berle and Means Corporation, 34 SeatTLE U. L. REv. 1121, 1124, 1133-34 (2011).

163 See, e.g., Jeffrey N. Gordon, Corporations, Markets, and Courts, 91 Colum. L. REv. 1931 (1991).

164 See Lawrence A. Cunningham, Intermediary Influence and Competition: Berkshire Versus KKR, 82 U. ChI. L. Rev. Dialogue 177, 181, 187-89 (2015). 
and Google-is large block shareholdings. ${ }^{165}$ No raider during the heyday of the hostile takeover and no shareholder activist today would consider targeting Berkshire. ${ }^{166}$ Indeed, Buffett famously aligned with the defenders of corporate bastions during the 1980s hostile takeover wave, as Berkshire provided takeover defense to companies such as Gillette by acquiring substantial convertible preferred stock and, in the case of Scott Fetzer, acquired the entire company as a white knight to defeat a hostile bid. ${ }^{167}$

But the calculus may differ after Buffett departs from the scene. After all, despite a market capitalization of nearly a half-trillion dollars, many analysts calculate that Berkshire is worth more - that the sum of the parts is greater than the whole and certainly substantial multiples of book value. ${ }^{168}$ Indeed, Berkshire invariably recovers its purchase price on acquisitions and investments rapidly, amid rising economic goodwill, while recording acquisitions at cost less depreciation, driving a huge wedge between intrinsic value and book value. ${ }^{169}$

Citing criticisms of the conglomerate business model, activists will urge Buffett's successors to sell Berkshire's struggling units, spin off the mediocre ones, and install new

165 See Deborah A. DeMott, Agency Principles and Large Block Shareholders, 19 CARDOZO L. REV 321, 321, 334 (1997).

166 See Cunningham, BerkshiRe Beyond BuffetT, supra note 6, at 198-99, 203, 210.

167 Cunningham, supra note 2, at 17.

168 See, e.g., Drew WoOdBury \& GregGory Warren, Morningstar Institutional Equity Res., What's the Best Way to Value Berkshire HATHAWAY? 13-21 (Feb. 19, 2013), http://msi.morningstar.com/Image/ BRKvaluation.pdf [http://perma.cc/LA83-9AD3]. Separately value and sum the major components of Berkshire and compare the result to the company's market capitalization: BH Energy, BNFS, the three principal insurance companies (Gen Re, GEICO, National Indemnity), the finance companies (led by Clayton Homes), the vast manufacturing and services operations, and the portfolio of investments (alone worth at least $\$ 120$ billion).

169 See The Essays of Warren Buffett, supra note 15, at 226-47. 
managers at some. ${ }^{170}$ In the process, activists would call for distributing cash to shareholders. They would explain how the net effect of such sales and distributions would increase immediate value for shareholders.

The counterargument will stress the long-term value for Berkshire shareholders of ironclad pledges to business sellers of a permanent home offering managerial autonomy and an environment in which vast amounts of capital can be moved from one subsidiary to another without taxes or transaction fees. ${ }^{171}$ The economic value of such commitments and flexibility is not necessarily reflected in Berkshire's prevailing stock price or the valuations of individual subsidiaries. The premium may only manifest itself when Berkshire makes an acquisition and be preserved only by sustaining the conglomerate.

Beyond the merits of such a debate, the defenses available to a corporation facing such activism will assume some importance, meaning that the Berkshire model may also offer lessons about the market for corporate control-the world of takeovers. Berkshire's corporate governance insulates it from activist shareholder agitation, starting with its dual class capital structure. Such structures are controversial if adopted as a takeover defense when they coerce stockholders to choose liquidity in exchange for surrendering control or in general because of the disparity between economic and voting rights.

But Berkshire's structure was adopted two decades ago to protect its shareholders by deterring intermediaries from creating trusts hawking fractional interests in the stock. ${ }^{172}$ Still, the Class A shares-where Buffett and other long-time

170 See Cunningham, Berkshire Beyond Buffett, supra note 6, at 208, 218-20. For a taste of such advocacy, see Life After Warren, ECONOMIST (Apr. 26, 2014), http://www.economist.com/news/leaders/2160 1255-all-his-success-building-great-corporation-warren-buffett-shouldnow-contemplate [https://perma.cc/P2D5-JMN4].

171 Cunningham, Berkshire Beyond Buffett, supra note 6, at 19596, 218-20.

172 See Robert W. Hamilton, Reflections on the Pricing of Shares, 19 CARdozo L. REV. 493, 500, 503 (1997). 
owners hold most of their stakes-command a significant multiple of the vote compared to the Class B shares. ${ }^{173}$ After Buffett's death, his bloc, currently at thirty-four percent of the vote, will be gradually sold over as many as ten years, providing his legatees with enduring though incrementally waning control. ${ }^{174}$

Berkshire's charter provides for the annual election of every board seat, making it theoretically possible for an insurgent to gain control of a majority in a single year. To check that, consideration might be given now to amending the charter, by board and shareholder vote, to opt for a staggered board with three classes of directors each serving three-year terms. That would promote continuity and independence while demanding greater patience from activists. It would also be a controversial move, however, as the recent debate over classified boards drew impassioned views on the subject. ${ }^{175}$ Berkshire has never had, but has never needed, a classified board; its culture and history are congruent with a classified board. ${ }^{176}$

173 Today, Class A shares have one vote per share and an equivalent claim to the economic interest such as dividends while the Class B shares have 1/10,000 of that voting power and 1/1500 of that economic interest. Recent stock market prices have been $\$ 200,000$ for Class A shares and $\$ 130$ Class B shares.

174 See Cunningham, Berkshire Beyond Buffett, supra note 6, at 193-210.

175 See Brian Baxter, Spat Over Staggered Corporate Boards Pits Wachtell Against Harvard's Bebchuk, AM. L. DAILY (Mar. 21, 2012, 7:00 PM), http://amlawdaily.typepad.com/amlawdaily/2012/03/wachtell-harv ard-shareholder.html [http://perma.cc/P434-GFW3] (noting duel between Lucian Bebchuk advocating for widespread repeal of classified boards and Martin Lipton vigorously opposing the campaign).

176 Another tool to consider: a charter amendment providing that all director nominations are to be made by the incumbent board rather than through the fashionable alternative that lets shareholders adopt bylaws requiring the corporation to let certain large and longer-term shareholders nominate directors. 


\section{Emulation}

Many people are interested in replicating Berkshire Hathaway, from the current leadership of Google to smaller insurance companies such as Markel Corporation, which has consciously mimicked the model quite successfully on a lesser scale. Many Berkshire subsidiaries are themselves conglomerates, genuine mini-Berkshires including not only Marmon and Scott Fetzer but also Berkshire Hathaway Energy, MiTek, and Precision Castparts. Business people dream of creating conglomerates in Berkshire's image in much the same way proverbial literary types want to write the next best-selling novel. And it can be done, if not on the same scale or to the same degree. More modest aspirations would emulate some of Berkshire's principles and practices, especially those of autonomy, decentralization, permanence, self-reliance, and trust.

Adapting the Berkshire model can create a competitive advantage versus rivals in the acquisition market, from strategic buyers to private equity firms. GE, for example, cannot offer autonomy or permanence. It is very acquisitive, but nearly as prone to divestitures-former CEO Jack Welch became famous for closing or selling any subsidiary that failed to lead its industry and Jeff Immelt executed a significant divestiture program. Private equity firms are interventionist by strategy and short-term by design. They create funds with ten-year lives (five to sow then five to reap) and immediately alter target managers, cultures, workforces, and production facilities to prepare the company for resale. ${ }^{177}$

Above all and for every public company, the most important lesson from Berkshire is the value of a long-term outlook. When public company managers are hounded by analysts and activist shareholders about results in the current quarter and year-to-date, the pressure to focus on the short-term is intense. Cutting costs today and

177 See, e.g., David Carey \& John E. Morris, King of Capital: The Remarkable Rise, Fall, and Rise Again of Steve Schwarzman and BLACKSTONE (2010). 
maximizing revenue now easily entail a sacrifice in future economic gain. The gains from withstanding short-term pressure to focus on results over the coming several years compound over time. The best emulators of Berkshire are companies and managers who earn reputations for serious long-term focus by achieving high average annual returns over rolling periods of five and ten years. That can be done in many different ways, using a variety of board structures, management techniques, and corporate cultures-all of which have costs as well as benefits and of which many varieties should be allowed to flourish.

\section{CONCLUSION}

People often say one's best quality is also one's worst quality and the same goes for Buffett and the Berkshire model he minted. It has been a huge plus for him to control investments and acquisitions, hire managers and give them autonomy in a decentralized structure-and those are the source of substantially all the costs of the Berkshire model as well. For others certainly, and maybe even for Buffett, easing up on the model in favor of a degree of the more conventional approaches might reduce some costs while sacrificing less in the way of gains. There is no reason to second-guess Buffett but every reason to believe that his successors will be drawn to making some adjustments.

But Berkshire and other companies should be permitted to devise the governance and organizational structures that work for them, whether the advisory or monitoring board, powerful or constrained executives, trust or control based cultures, and concentrated or diversified business organizations. While even Berkshire can improve, it shows that, warts and all, the conventional wisdom in corporate governance and practice is not always efficient or wise. 